\title{
Significant Contribution of Temperature on AISI D2 Tool Steel Ground Surface Characteristics and Integrities
}

Brahim Ben Fathallah ( $\sim$ brahim.benfathallah@enit.utm.tn )

National Engineering School of Tunis: Ecole Nationale d'Ingenieurs de Tunis https://orcid.org/00000002-1793-2846

\section{Mohamed Rawen}

AV Taha Hussein Montfleury

\section{Research Article}

Keywords: Grinding temperature, Residual stress, FEM, controlled grinding, Surface integrity, AISI D2

Posted Date: June 4th, 2021

DOl: https://doi.org/10.21203/rs.3.rs-542165/v1

License: (c) (i) This work is licensed under a Creative Commons Attribution 4.0 International License.

Read Full License 


\title{
Significant contribution of temperature on AISI D2 tool steel ground surface characteristics and integrities
}

\section{Authors: Brahim BEN FATHALLAH ${ }^{1,2}{ }^{*}$, Mohamed RAWEN ${ }^{1}$}

\section{Brahim BEN FATHALLAH ${ }^{1,2}$}

E-mail Adress: $\underline{\text { brahim.benfathallah@enit.utm.tn }}$

Fax:+216 70860548

Telephone number: +216 58495479

Affiliation:

${ }^{1}$ Mechanical, Material and Process Laboratory (LR99ES05) ENSIT, 5 AV Taha Hussein Montfleury, Tunis, Tunisia

${ }^{2}$ University of Tunis El Manar, ENIT, Applied Mechanics and Engineering Laboratory (LR-11-ES19), BP 37 Le Belvédère 1002, Tunis, Tunisia

\section{Mohamed RAWEN ${ }^{1}$}

E-mail Adress: med.rawen2021@gmail.com

Fax:+216 70860548

Telephone number: +21698692867

Affiliation:

${ }^{1}$ Mechanical, Material and Process Laboratory (LR99ES05) ENSIT, 5 AV Taha Hussein Montfleury,

Tunis, Tunisia

* Corresponding author: Brahim Ben Fathallah

Contact e-mail: brahim.benfathallah@enit.utm.tn

Tel.: +216 58495479

\begin{abstract}
The Controlled grinding is governed by the maximum surface temperature in the wheel-workpiece interaction. In this study, we demonstrate that temperature is the significant controller on the surface characteristic grinding, the surface integrity, the productivity and the fatigue life. Moreover, high temperature generated in abrasive processes is the main factor responsible on ground surface damage and its impact on the induced consequences in grinding of AISI D2 tool steel. The combined effects of abrasive type, cooling mode according to the cutting depth, on the temperature and residual stress distribution were highlighted by exploiting FEM. Obtained numerical results were validated with the experimental ones.
\end{abstract}

Keywords: Grinding temperature, Residual stress, FEM, controlled grinding, Surface integrity, AISI D2 


\section{Nomenclature}

$\mathrm{v}_{\mathrm{s}}, \mathrm{v}_{\mathrm{w}}$ and $\mathrm{a}_{\mathrm{w}} \quad$ The wheel speed, the work speed and the depth of cut

$b_{\mathrm{s}}$

Grinding widh

$\mathrm{d}_{\mathrm{s}} \quad$ Grinding wheel diameter

$\mathrm{h}_{\mathrm{eq}} \quad$ Equivalent chip thickness $(\mu \mathrm{m})$

lc grinding length $(\mathrm{mm})$

$\mathrm{F}_{\mathrm{t}} \quad$ Tangential grinding force

$\varepsilon_{0}$ Fraction of the net grinding power entering the workpiece

C Specific heat $\left(\mathrm{J} \mathrm{kg}^{-1} \mathrm{~K}^{-1}\right)$

$\mathrm{F}_{1 \mathrm{t}} \quad$ Tangential grinding force for the equivalent chip thickness equal to one

$\mathrm{F}_{\mathrm{t} 1}^{\prime} \quad$ (N)Tangential force per unit length for an equivalent chip thickness $\left(\mathrm{N} \mathrm{mm}^{-1}\right)$

h coefficient Heat exchange $\left(\mathrm{W} \mathrm{m}^{-2} \mathrm{~K}^{-2}\right)$

k Constant

n Exponent

$\mathrm{P}_{\mathrm{m}} \quad$ net grinding power $(\mathrm{W})$

$\mathrm{P}_{\mathrm{th}} \quad$ total heat power generated by the grinding process (W)

$\mathrm{P}_{\mathrm{w}} \quad$ net grinding energy entering the workpiece (W)

$\mathrm{S}_{\mathrm{c}} \quad$ contact area between the grinding wheel and the workpiece $\left(\mathrm{mm}^{2}\right)$

$\mathrm{X} \quad$ curvilinear abscissa associated with the contact area $(\mathrm{mm})$

$\varepsilon \quad$ fraction of the net grinding power entering the workpiece

$\theta \quad$ temperature computed in integration point $\left({ }^{\circ} \mathrm{C}\right)$

$\theta_{0} \quad$ initial temperature of the workpiece $\left({ }^{\circ} \mathrm{C}\right)$

$\lambda \quad$ thermal conductivity of the workpiece $\left(\mathrm{W} \mathrm{m}^{-1} \mathrm{~K}^{-1}\right)$

$\rho \quad$ workpiece density $\left(\mathrm{kg} \mathrm{m}^{-3}\right)$

$\mathrm{d} \tau_{\mathrm{r}} \quad$ volume of removed material during $\mathrm{dt}$

$\mathrm{d} \tau_{\mathrm{r}} / \mathrm{dt} \quad$ material removal rates $\left(\mathrm{m}^{3} \mathrm{~s}^{-1}\right)$

$\varphi \quad$ net heat flux density $\left(\mathrm{W} \mathrm{mm}^{-2}\right)$

$\varphi c \quad$ part of the net heat flux going through the chip and the grinding fluid $\left(\mathrm{W} \mathrm{mm}^{-2}\right)$

पS part of the net heat flux going through the grinding wheel $\left(\mathrm{W} \mathrm{mm}^{-2}\right)$

$\varphi \mathrm{W}$

$\sigma_{x x}^{R}, \sigma_{y y}^{R}$

$\overline{\overline{\sigma_{R e s}}}(\mathbf{t})$

part of the net heat flux going in the workpiece $\left(\mathrm{W} \mathrm{mm}^{-2}\right)$

Initial residual stresses in $\mathrm{X}$ - and $\mathrm{Y}$ - directions, respectively

Residual stress tensor 


\section{Introduction}

Grinding operations of tool steels involve cutting forces and heat fluxes which generate gradients of properties in the surface layers $[1,2]$. The grinding process requires a combination grinding (abrasive type - cooling mode - cutting conditions) [3,4]. This combination controls the wheel - workpiece interaction and the superficial modifications $[3,5,6]$. Consequently, this results in gradient surfaces with microstructural and mechanical properties that can compromise the life integrity of the finished or machined workpiece [7-9]. Several studies have been devoted to the identification of these interactions and their quantitative evaluation using experimental approaches [10-12], analytical models [6,13,14] and numerical simulations [14-17]. The resolution of this problematic requires the development of an experimental and / or a numerical evaluation methodology. This result allows to correlate industrial needs to combinations grinding (abrasive type - cooling mode - cutting conditions) through their adequate choice sweeping the areas of low and high productivity. However, the proportion of heat conducted into the workpiece (heat partition ratio) was estimated an experimental approach based on the temperature measurement sufficiently near the grinding zone is required. The temperature and microstructure gradients of the affected layers create plastic deformation incompatibilities generating residual stress and strain distributions. Such distributions are extensively studied in the literature $[5,6,18]$. The residual stress profiles were established by either experimental measurements using the following methods $[9,19,20]$, and by modelling and numerical simulations of the grinding process $[18,21,22]$. Generally the distributions resulting from alloyed steel grinding relate to the grinding wheel parameters (nature of the abrasive, type of dressing, ...) [23,24], the nature of the material to be machined (behaviour law, thermophysical characteristics) [25], the lubrication mode [3,26,27] and the cutting conditions $\left(a_{w}, v_{w}, v_{s}\right)$ [18,28,29]. The following results of the effects of grinding parameters on the property gradients (temperature and residual stresses), through literature, reveal that the surface temperatures are higher for grinding with soluble oil than for cryogenic grinding of steel EN X210CrMoV12, as well as, the temperatures reached at the surface increase with increasing depth of cut $\left(a_{w}\right)$ [28]. Lin shows that the temperature rises from $\mathrm{T}=100^{\circ} \mathrm{C}$ for $\mathrm{a}_{\mathrm{w}}=10 \mu \mathrm{m}$ to $\mathrm{T}=150^{\circ} \mathrm{C}$ for $\mathrm{a}_{\mathrm{w}}=50 \mu \mathrm{m}$ [30]. The surface temperature of grinding alloy steel (100Cr6) reached decreases with the rise of the table speed $\left(\mathrm{v}_{\mathrm{w}}\right)$ [31]. Lefebvre shows that in grinding of AISI 1045 (C45) steel that the temperature changes from $\mathrm{T}=370^{\circ} \mathrm{C}$ for $\mathrm{v}_{\mathrm{w}}=100 \mathrm{~mm} / \mathrm{s}$ to $\mathrm{T}=200^{\circ} \mathrm{C}$ for $\mathrm{v}_{\mathrm{w}}=300 \mathrm{~mm} / \mathrm{s}$ [32], the surface temperature reached decreases as the cutting speed (vs) increases. Hamdi [21], shows in the case of $100 \mathrm{Cr} 6$ steel that the temperature goes from $\mathrm{T}=200^{\circ} \mathrm{C}$ for $\mathrm{v}_{\mathrm{s}}=$ $30 \mathrm{~m} / \mathrm{s}$ to $\mathrm{T}=100^{\circ} \mathrm{C}$ for $\mathrm{v}_{\mathrm{s}}=120 \mathrm{~m} / \mathrm{s}$ [21] and the maximum temperatures at the ground surface of the steel increase with the decrease of the linear speed table $\left(v_{w}\right)$. Stephenson [33] attributes the increase in surface temperature to the increase in wheel-to-work friction. 
It is well established in the literature that material interactions in the grinding process lead to changes in the surface layer properties of the workpiece [3,5,28,34]. Such modifications cover the microgeometrical [6,35], microstructural [12,20,36] and mechanical [5,7,37] aspects. The magnitude and extent of these modifications depend on the thermophysical and microstructural characteristics of the material to be machined, the grinding wheel $[6,7]$, the lubrication conditions [2,3] and the cutting conditions $\left(\mathrm{a}_{\mathrm{w}}, \mathrm{v}_{\mathrm{w}}, \mathrm{v}_{\mathrm{s}}\right)$ [38,39].

The Controlled grinding is governed by the temperature in the wheel-workpiece interaction. Moreover, the surface temperature is the significant controller of the surface characteristic grinding. In this study, we developed the combination effect of the abrasive type and the cooling mode of the tool steel AISI D2 (EN X160CrMoV12) on the temperature distribution and residual stresses. In this context, that a contribution is made through finite element modeling by using the ABAQUS code with FORTRAN programmed subroutines (dflux, film and dload). Therefore, we propose to evaluate the gradients of surface layer properties resulting from the modifications generated by the various material interactions - process (surface grinding) according to the wheel type - cooling mode - cutting condition combinations described above. This evaluation was established using an experimental approach based on a methodology for identifying microgeometric, microstructural and mechanical characteristic profiles in the affected layers by combining various mechanical and physical investigation techniques. 


\section{The numerical prediction of residual stress gradients}

This approach consists to reproduce the genesis mechanisms of residual stresses in the surface layers of the workpiece grinding by the simulation of the interaction wheel - workpeace of the ground surface AISI D2 (Stage 1). It was followed by a simulation of cooling by convection (Stage 2). This interaction is modeled by a distribution of heat flow comparable length of the contact ground surface / subsurface is $\left(l_{c}\right)$. This flux moves according to the longitudinal direction at the table speed $\left(\mathrm{v}_{\mathrm{w}}\right)$. The distribution of the temperatures in the surface layers is found starting from the first simulation. The residual stresses are found at the end of stage 2, in accordance with the flow chart (Figure 1).

The finite element model containing the varied coefficients of friction is established in order to improve the prediction accuracy of surface grinding temperature of particulate reinforced. Numerical modelling of the part's behavior under grinding conditions requires the thermomechanical behavior of the workpiece material. Several constitutive models are used. However, the Johnson \& Cook relationship (Equation 1) is probably the most used of the commercial FE codes, with only the terms related to Elasto-plasticity and temperature sensitivity [40,41]. This model constants and exponents (A, B, n, n, m) provided in the literature are reported in Table $1[42,43]$.

$$
\sigma=\left(A+B\left(\varepsilon_{e q}^{p}\right)^{n}\right)\left(1+C\left(\frac{\dot{\varepsilon}}{\dot{\varepsilon}_{0}}\right)\right)\left(1-\left(\frac{T-293}{T_{M}-293}\right)^{m}\right)
$$

Where $\sigma$ et $\varepsilon_{e q}^{p}$ : the material's yield strength and equivalent plastic yield strain; $\dot{\varepsilon}_{0}$ is the reference strain-rate $\left(3500 \mathrm{~s}^{-1}\right)$ and $\mathrm{T}_{\mathrm{M}}$ : the melting temperature of the material, Constitutive law coefficients for hardened AISI D2 tool steel

The constants $(\mathrm{A}, \mathrm{B}, \mathrm{n})$ are validated by a tensile stress test on the AISI D2 tool steel. Tensile strength curves at different temperatures (Figure 2) were established, using the exponent (m), describing the temperature sensitivity, provided in the literature (Table 1). These curves are introduced step by step into the calculation code used (Abaqus Standard) to describe the behaviour of the material. The mechanical and thermophysical characteristics of AISI D2 steel, depending on temperature, are shown in Table 2. These characteristics are introduced in the calculation code (Abaqus Standard)

The spatial and temporal distributions of the grinding temperatures $\mathrm{T}(\mathrm{x}, \mathrm{y}, \mathrm{t})$ resulting from the studied combinations (abrasive grain, cooling mode and cutting conditions (A-C-Cc)) would be the solution of the heat equation, in continuous regime (Equation 2).

$$
\lambda\left(\left(\frac{\partial^{2} T}{\partial x^{2}}\right)+\left(\frac{\partial^{2} T}{\partial y^{2}}\right)\right)=\rho . C_{p} \frac{\partial T}{\partial t}
$$




\section{- The initial and boundary conditions}

The initial temperature is set through the structure at $\mathrm{T}_{0}=20^{\circ} \mathrm{C}$.

Heating of the workpiece during grinding results in a positive heat flux to the workpiece at the grinding zone, and convective cooling by the grinding fluid results in a negative heat flux from the workpiece (Figure 3).

The heating uniform distributions of the workpiece at the grinding zone are applied over the contact length of the workpiece grinding wheel $\left(1_{c}\right)$ (Equation 3). This heat flux is distributed approximately linearly in the reference $\mathrm{R}^{\prime}\left(\mathrm{o}, \mathrm{x}^{\prime}, \mathrm{y}^{\prime}\right)$ by the limit condition given by the relationship (Equation 4). Heat flux is followed by grinding fluid results from the workpiece. A convection heat transfer coefficient for cooling $\left(\varphi_{1}\right)$ according to the conditions given by the relationship (Equation 4). In addition, convection is done in the open air through a flow (air) (Equation 4).

$$
l_{c}=\sqrt{a_{w} \cdot d_{s}}
$$

where, $a_{w}$ is a depth of cut and $d_{s}$ is a grinding wheel diameter either $d_{s}=300 \mathrm{~mm}$

$\varphi\left(\mathrm{x}^{\prime}\right)=\left\{\begin{array}{c}\varphi_{\mathrm{P}}=\varepsilon^{\prime} \cdot \frac{F_{t} \cdot v_{s}}{b_{s} \cdot l_{c}}, \text { for }-\frac{\mathrm{l}_{\mathrm{c}}}{2} \leq \mathrm{x}^{\prime} \leq \frac{\mathrm{l}_{\mathrm{c}}}{2} \text { and } \mathrm{y}=0 \\ \varphi_{\mathrm{l}}=\mathrm{h}_{\mathrm{lub}}\left(\mathrm{T}-\mathrm{T}_{0}\right) \text { for } \mathrm{x}^{\prime}>\frac{\mathrm{l}_{\mathrm{c}}}{2} \text { and } \mathrm{y}=0 \\ \varphi_{\mathrm{air}}=\mathrm{h}_{\mathrm{air}}\left(\mathrm{T}-\mathrm{T}_{0}\right) \text { for } \mathrm{x}^{\prime}<-\frac{\mathrm{l}_{\mathrm{c}}}{2} \text { and } \mathrm{y}=0\end{array}\right.$

With:

- $\quad F_{t}$ the tangential cutting force, $v_{s}$ peripheral grinding wheel speed and $b_{s}$ the workpiece width

- $\quad \varepsilon^{\prime}:$ is a fraction initially defined as $\varepsilon^{\prime}{ }_{0}=0,65$ [21]. It is adjusted on the basis of the temperatures measured according to the flow diagram (Figure 3).

- $h_{\text {air }}$ et $h_{\text {lub }}$ : air and lubrifiant convection coefficients respectively ( $h_{\text {cryo }}$ ou $\left.h_{H S}\right)$. The values of these coefficients are initially selected from table 3 and they are adjusted on the basis of the residual stresses measured according to the flow diagram (Figure 1).

The value of the heat flux $\left(\varphi_{p}\right)$ corresponding to each combination (Abrasive type - Cooling mode and - cutting depth (A-C-Cd)) and specific to each calibration is shown in table 3.

The heat flux center $\left(\varphi_{\mathrm{p}}\right)$ is located initially at the position $\mathrm{x}_{0}=-15 \mathrm{~mm}$ and $\mathrm{y}_{0}=0$ in the reference $\mathrm{R}(\mathrm{O}, \mathrm{x}, \mathrm{y})$. Its motion is simulated by a relative displacement between a reference point related to the heat source $\mathrm{R}^{\prime}\left(\mathrm{O}, \mathrm{x}^{\prime}, \mathrm{y}^{\prime}\right)$ and a reference point $\mathrm{R}(\mathrm{O}, \mathrm{x}, \mathrm{y})$ related to the workpiece. The abscissa of the centre of the moving heat flow is written in the following mark $\mathrm{R}$ :

Such as : $\quad \boldsymbol{x}^{\prime}=\boldsymbol{x}-\boldsymbol{v}_{\boldsymbol{w}} \cdot \boldsymbol{t}$, which $\mathrm{v}_{\mathrm{w}}=\left(\frac{\Delta x}{\Delta t}\right)$

The boundary conditions in reference $\mathrm{R}(\mathrm{O}, \mathrm{x}, \mathrm{y})$ are written (Equation 5) : 


$$
\varphi(\mathrm{x})=\left\{\begin{array}{c}
\boldsymbol{\varphi}_{\mathrm{P}}, \text { for }-\frac{l_{w}}{2}-\frac{l_{c}}{2}+\left(\frac{t}{\Delta t}\right) \cdot(\Delta x) \leq \mathbf{x} \leq-\frac{l_{w}}{2}+\frac{l_{c}}{2}+\left(\frac{t}{\Delta t}\right) \cdot(\Delta x) \text { and } \mathrm{y}=0 \\
\varphi_{\text {lub }}, \text { for } \mathrm{x}<-\frac{l_{w}}{2}+\frac{l_{c}}{2}+\left(\frac{t}{\Delta t}\right) \cdot(\Delta x) \text { and } \mathrm{y}=0 \\
\varphi_{\text {air }}, \text { for } \mathrm{x}>-\frac{l_{w}}{2}-\frac{l_{c}}{2}+\left(\frac{t}{\Delta t}\right) \cdot(\Delta x) \text { and } \mathrm{y}=0
\end{array}\right.
$$

which :

$\Delta \mathrm{x}$ : The displacement of the flow center from node (n) to node $(\mathrm{n}+1)$ taken equal to $0,3 \mathrm{~mm}$.

$\Delta \mathrm{t}$ : The time interval corresponding to a displacement of the flow from $\Delta \mathrm{x}$.

$$
\Delta t=\frac{\Delta \mathbf{x}}{v_{W}}=\frac{0.3}{150}=0.002 s
$$

This displacement is carried out digitally using a DFLUX Subroutine written in Fortran and called by Abaqus standard when the calculation is performed.

\section{- Spatial discretization:}

The mesh size of the area to be affected by the process is about $1 \mathrm{~mm}$ in thickness and has been refined to a minimum size of $94 \mu \mathrm{m}$ to improve computational accuracy (Figure 4). The geometry of the sample was discretized in space by 3400 elements of the CPE4RT type (4-node quadrilateral elements, in plane deformation, with reduced integration thermal coupling and bilinear displacement) adapted to this type of calculation and available in the element library of the calculation code used.

\section{- Numerical simulation results}

The results reveal characteristics such as surface temperature and the width of the affected areas. The characteristics are as shown in the figure. Surface temperature values between $20^{\circ} \mathrm{C}<\mathrm{T}<430^{\circ} \mathrm{C}\left(\mathrm{a}_{\mathrm{w}}=15 \mu \mathrm{m}\right)$ and $20^{\circ} \mathrm{C}<\mathrm{T}<817^{\circ} \mathrm{C}\left(\mathrm{a}_{\mathrm{w}}=30 \mu \mathrm{m}\right)$ are found.

The thicknesses of the thermally affected layers varied from $\left(e_{a}>50 \mu \mathrm{m}\right)$ to $\left(e_{a}=150 \mu \mathrm{m}\right)$. The distributions of residual stresses induced by grinding.

\section{Effect of combination (A-C-Cd) on the temperature evolution on grinding surface: numerical approach}

The thermomechanical interaction resulting from grinding simulation using the standard abaqus code corresponding to the combined effects of abrasive type, cooling mode and cutting depth (A-CCd) were reported in Table 5. The thermal fields, on the affected layers, resulting from different combinations revealed characteristics such as maximum grinding temperature and residual stress profile as shown in Figures 5-8. 
The numerical result of température gradient evolution, obtained with the Abaqus standard code, are presented in Table 5. They are shown, the effect of depth of cut on the temperature of the grinding AISI D2 tool steel. It was revealed the evolution of temperature versus time at various surface locations as shown in Figure 5 and 6 . The thermal affected layer thickness varies from $\left(e_{a}=50 \mu \mathrm{m}\right)$ to $\left(e_{a}=150 \mu \mathrm{m}\right)$. Similarly, the residual stress distributions induced by grinding (Figure 8 ) reveal the effect of combinations (A-C-Cd) on stress profile characteristics such as maximum surface stress and layer thickness under residual stress. These characteristics are reported for the different combinations parameter (A-C-Cd) have been studied from low to high productivity $\left(\mathrm{a}_{\mathrm{w}}=15-40 \mu \mathrm{m}\right)$ as shown in Table 5. Large spectra of stress variations ranging from residual stress compression $\sigma^{\mathbf{R}}=-500 \mathrm{MPa}\left(\mathrm{a}_{\mathrm{w}}=15 \mu \mathrm{m}\right)$ to high tensile residual stress $\sigma^{\mathbf{R}}=1150 \mathrm{MPa}\left(\mathrm{a}_{\mathrm{w}}=40 \mu \mathrm{m}\right)$ are shown. The widths of the layers under residual stress vary from $\left(e_{c}=50 \mu \mathrm{m}\right)$ to $\left(e_{c}=300 \mu \mathrm{m}\right)$.

\section{Experimental validation}

This part is aimed to validate, experimentally, the effects of combinations (abrasive type, cooling mode and cutting depth) on temperature and residual stresses in surface and sub-surface in plunge grinding. A good correlation is found between the simulated and measured profiles, as framed by their error bars. The validation of the temperature distributions was carried out by using the experimental database for the $\mathrm{Al}_{2} \mathrm{O}_{3}$ abrasive grain using all combinations in conventional grinding of AISI D2 steel.

\subsection{Experemental approach : Temperature evolution}

The quasi-stationary state is well reached upstream of the junction but the maximum temperature increases before the sensor and decreases afterwards. This is due to the very low thermal conductivity of the mica which constitutes a thermal barrier. As a result, the cooling curves are almost merged following the heat source flow.

The assembly of the calibrated RC filter circuit is prepared as a whole (Room, Oscilloscope, RC circuit) taking into account the assembly of the thermocouple for surface temperature measurement (Figure 8,9 and 10). Grinding experiments using the effect of depth of cut $\left(\mathrm{a}_{\mathrm{w}}=15 \mu \mathrm{m}\right.$ and $\left.\mathrm{a}_{\mathrm{w}}=50 \mu \mathrm{m}\right)$ on the température surface of the AISI D2 using the conventional cooling mode combined with Sol gel abrasive type ( $S G C C)$ with conventional conditions $\left(\mathrm{v}_{\mathrm{w}}=9 \mathrm{~m} / \mathrm{min}\right.$ and $\left.\mathrm{v}_{\mathrm{s}}=22 \mathrm{~m} / \mathrm{s}\right)$.

\subsection{Experimental approach : Residual stress evolution}


The validation of numerical residual stress gradient simulations is based on the results of X-ray diffraction measurements performed in this study for different combinations (A-C-Cc) (Figure 12). A good correlation is found between the simulated and measured profiles, as framed by their error bars. This procedure allows the effects of the different combination elements (A-C-Cd) on the residual stress distributions induced by grinding (Figure $12 \mathrm{a}$ and $\mathrm{b}$ ). The validation of the temperature distributions was carried out by using the experimental database for the $\mathrm{Al}_{2} \mathrm{O}_{3}$ abrasive grain using all combinations in conventional grinding of AISI D2 steel studied by S. Paul [4]. The numerical simulation data, obtained by the procedure developed in this study, are compared with S. Paul's experimental results (Table 6). A satisfactory prediction is obtained within the experimental dispersion range provided by the author.

\section{Discussion:}

Analysis of the results obtained in this study highlight the effect of combinations (A-C-Cd): abrasive type - cooling mode - cutting depth, on the microgeometric, microstructural and mechanical characteristics of AISI D2 tool steel surfaces generated by the grinding process. The combinations studied involves the conventional grinding with the various modes of material tool interaction (cutting forces, friction and temperatures) and their consequences on roughness, surface softening of the microstructure, residual stresses and characteristics of the thermal crack network. The results of the numerical simulation showed that mechanical exchanges and in particular the contact pressure between grinding wheel and part, characterized by normal cutting forces, do not seem to have a significant effect on surface characteristics, due to their low intensity. Many studies related to the grinding of steels confirm this finding $[6,21,46]$. Therefore, the temperatures generated at the wheel / workpiece interaction is of increasing significance in the sense that they govern most of the changes in the surface layers, whether microstructural, microgeometric or mechanical.

\subsection{Effects of the grinding temperature on the Microstructural surface characteristic}

The superficial softening of the ground surface layers of AISI D2 tool steel shows a microstructural evolution phenomenon generated by the temperature increases at the grinding wheel - workpiece interaction independently of the combinations (A-C-Cc) applied (figure 13). This result is in accordance with the literature and particularly with Murthey's [39] and Zhejun's [47] work on micro alloy steel $18 \mathrm{MnNi} 2$ and low-alloy steel $100 \mathrm{Cr} 6$ respectively. It can be used to translate the effect of combinations by the temperatures generated at the grinding wheel - workpiece interaction. This evolution can vary from the simple tempering of the basic martensite (a slightly decreased hardness) to a partial austenitization (a significantly decreased hardness). Surface austenitization, induced by 
grinding the martensite of AISI D2 tool steel, seems to occur at lower temperatures (around $800^{\circ} \mathrm{C}$ ) than predicted by the equilibrium charts (around $1080^{\circ} \mathrm{C}$ - pseudo-binary diagram fe-C). This suggests that the high deformations accelerate the decomposition kinetics of martensite, which appears to occur at relatively lower temperatures [3]. This point deserves further investigation in relation to the microstructure of the white layer, if any, highlighted by Shaji [48], in the case of the grinding of low-alloy steels.

\subsection{The effects of the grinding temperature on the Microgeometrical surface characteristic}

The elementary mechanisms of material removal by single abrasive grains is based to referring this result. We can understand that the roughness, traces of large deformations of the surface layers, is essentially controlled by the contact pressure (at each grain) and by the behaviour of the material under the extreme loading conditions. This control is imposed by the process (speed, temperature and deformation mode) such as :

- the contact pressure of each grain depends on the stability of its geometry during grinding (wear, flattening, regeneration and others).

- the behaviour of the material and in particular its aptitude for plastic deformation depends on the deformation rates and temperatures generated as well as the elementary deformation and rupture mechanisms (sliding and rise of dislocations, staining, cleavage, ductile rupture etc...)

These two factors largely explain the effects of combinations (A-C-Cd) on the roughness obtained :

- Under soft grinding conditions aw $<40 \mu \mathrm{m}$, the temperatures generated at the grinding wheel - workpiece interface remains less than or equal to $800^{\circ} \mathrm{C}$, corresponding to a tempered to a tempered martensite but brittle (Figure 14) which favours a chip formation mechanism by cleavage for both types of grinding wheels and both lubrication modes. As a result, the low effect of wheel type and lubrication mode on the arithmetic roughness Ra and total Rt. These evolve moderately as the running depth increases for all types of grinding wheel and lubricant as a result of the increase in temperature at the grinding wheel - workpiece interface and the contact pressure (Figure 14 (a) and (b)).

- Under severe grinding conditions aw $>40 \mu \mathrm{m}$, temperatures at the grinding wheel-material contact reachs higher temperatures $\left(800^{\circ} \mathrm{C}\right)$, favouring the decomposition of martensite into austenite with a higher plastic deformation characteristic by the phenomenon of rising dislocations. This suggests a higher roughness for all M.L.C. combinations. However, the contact pressure at each abrasive grain is modified by the regeneration phenomenon of the cutting edges. This phenomenon is attributed for Sol-Gel abrasives and flattening of $\mathrm{Al}_{2} \mathrm{O}_{3}$ abrasives highlighted in [3]. It was explained the higher roughness for surface ground with Sol-Gel abrasives for both conventional and cryogenic lubrication modes (Figure 14 (a) and (b)). 


\subsection{The effects of the grinding temperature on the Mechanical surface characteristic}

The effect of combinations (A-C-Cd) on the residual stress distributions of grinding can be understood as the predominant contribution of thermal stresses. These are all the more important as the higher temperatures reached at the grinding wheel - workpiece intersection ( Figure 15 (a) and (b)). Therefore, the residual surface stresses remain compressive for all combinations (A-C-Cc) that generate temperatures at the grinding wheel - workpiece interface less than or equal to $350^{\circ} \mathrm{C}$. These combinations correspond to the soft grinding conditions $(\mathrm{aw}<30 \mu \mathrm{m})$ with a Sol-Gel wheel and cryogenic lubrication by higher temperatures there is a linear relationship between the residual tensile stresses and the temperatures generated at the wheel - part interface of the shape:

$$
\sigma_{R}=2,16 \cdot T\left({ }^{\circ} \mathrm{C}\right)-750 .
$$

Likewise, the layer thickness undergoing the remaining grinding stresses is quite comparable to the depth of the layers thermally affected by the grinding process, regardless of the nature of the combinations applied (Figure 15 (a) and (b)). These results are in line with the findings of the literature presented in [3,7] referring to the specific effects of the different types of wheels $[47,49]$, lubrication modes [29,50] and cutting depth [5,27].

\subsection{The effects of the grinding temperature on the surface integrities}

The effect of combinations (A-C-Cd) on thermal crack distributions in the case of AISI D2 tool steel can be assessed by referring to the temperature generated at the grinding wheel - workpiece interface (Figure 17 (a) and (b)). Indeed, the crack density length is all the more important as the temperature generated on the surface of the part is higher. These two values, which are characteristic of the integrity of ground steel surfaces AISI D2, can be written as a function of the temperature at the grinding wheel - workpiece interface for all combinations (A-C-Cd) in the following manner:

$$
\begin{aligned}
& \left\langle I_{\text {moy }}>=0,049 \cdot T-15,95\right. \\
& \langle\rho>=0,252 . T-97,11
\end{aligned}
$$

These results reveal qualitatively and quantitatively the achievements of the literature presented in [3] regarding the effects of wheel type [47], lubrication mode [3] and cutting depth [4] on the grinding burn network.

\subsection{The effects of the grinding temperature on productivity}


The favorable combinations study of high productivity combined with better quality involves controlling the temperatures generated at the grinding wheel - workpiece interface. This combination is attributed to the low roughness and low level of residual tensile stresses and integrity, low density and length of thermal cracks of ground surfaces in AISI D2 tool steel (Figure 18). This approach shows that steel grinding productivity doubles when changing from an $\mathrm{Al}_{2} \mathrm{O}_{3}$ wheel with soluble oil lubrication to a Sol-gel wheel and cryogenic lubrication, also.

\section{Conclusion}

The temperature generated at the grinding wheel - workpiece interface reveals the characteristic parameter of the equivalence of the effect of combinations (A-C-Cd): abrasive type cooling mode - cutting depth of grinding. These temperatures range from $200^{\circ} \mathrm{C}$ (Sol-Gel grinding wheel, cryogenic lubrication and $\left.\mathrm{a}_{\mathrm{w}}=15 \mu \mathrm{m}\right)$ to $1200^{\circ} \mathrm{C}\left(\mathrm{Al}_{2} \mathrm{O}_{3}\right.$ grinding wheel, soluble oil lubrication and $\mathrm{a}_{\mathrm{w}}=100 \mu \mathrm{m}$ ), depending on the (A-C-Cd) combinations with two types of grinding wheels (Sol-gel and $\mathrm{Al}_{2} \mathrm{O}_{3}$ ), two cooling modes (soluble oil and liquid nitrogen) and various cutting depth $(5 \leq \mathrm{aw} \leq 200 \mu \mathrm{m})$. The thermally affected layers depth vary from 20 to $280 \mu \mathrm{m}$ depending on the (A-C-Cd) combination. This research seeks to extend the significant contribution of temperature on the characteristics and integrities of the ground surface of AISI D2 tool steel according to two approaches, numerical and experimental. The analysis highlight the effect of combinations (A-CCd): abrasive type - cooling mode - cutting depth, of microgeometric, microstructural and mechanical characteristics of AISI D2 tool steel surfaces generated by the grinding process. The main numerical, using Abaqus standard code, and experimental results are as follows:

- The numerical prediction approach of residual stress gradients in grinding is used in this research reveals characteristics such as surface temperature and the width of the affected areas. The surface temperature values are found between $20^{\circ} \mathrm{C}<\mathrm{T}<430^{\circ} \mathrm{C} \quad\left(\mathrm{a}_{\mathrm{w}}=15 \mu \mathrm{m}\right)$ and $20^{\circ} \mathrm{C}<\mathrm{T}<817^{\circ} \mathrm{C}\left(\mathrm{a}_{\mathrm{w}}=30 \mu \mathrm{m}\right)$. The thicknesses of the thermally affected layers varied from ( $\mathrm{e}_{\mathrm{a}}$ $>50 \mu \mathrm{m})$ to $\left(\mathrm{e}_{\mathrm{a}}=150 \mu \mathrm{m}\right)$.

- The experimental distributions of residual stresses and maximum temperature induced by grinding with for all combinations (A-C-Cd) corroborate the numerical approach with $10 \%$ error.

- The temperatures control the interaction wheel - workpiece interface. It was occurred in the surface layers the change within the microstructural evolution phenomenon generated by the temperature increases at the grinding wheel - workpiece interaction independently of the combinations (A-C-Cc).

- Using the controlled by the contact pressure, temperature and deformation mode, we demonstrate experimentally the surface roughness, traces of large deformations of the surface layers, is essentially caused by plastic deformation and depend on the deformation rates and temperatures 
generated to the elementary deformation and rupture mechanisms (sliding and rise of dislocations, staining, cleavage, ductile rupture etc...). These two factors largely explain the effects of combinations (A-C-Cd) on the microgemetrical, microstructural, mechanical, surface integrities and productivity are obtained the soft grinding conditions $\mathrm{a}_{\mathrm{w}}<40 \mu \mathrm{m}$, the temperatures generated at the grinding wheel - workpiece interface remain less than or equal to $800^{\circ} \mathrm{C}$, corresponding to a tempered to a tempered martensite but brittle which favours a chip formation mechanism by cleavage for both types of grinding wheels and both lubrication modes. Under severe grinding conditions aw $>40 \mu \mathrm{m}$, temperatures at the grinding wheel-material contact reach higher temperatures $\left(800^{\circ} \mathrm{C}\right)$, favouring the decomposition of martensite into austenite with a higher plastic deformation characteristic of the phenomenon of rising dislocations.

\section{Acknowledgements}

Authors are also thankful to Pr. Dr. Habib SIDHOM (President of University of Tunis, Tunisia) for his fruitful discussions, contribution and conceptualization and to Pr. Dr. Chedly BRAHAM (ENSAM Paris French) for the X-ray diffraction measurements of RS.

Availability of data and materials: Not applicable

Author contribution: Brahim BEN FATHALLAH (Conceptualization, modeling, simulation, and experimental analysis and writing, review, and editing) \& Mohamed RAWEN (experimental approach : Temperature evolution).

Funding Research is funded by LMMP (Mechanical, Material and Process Laboratory (LR99ES05) ENSIT, 5 AV Taha Hussein Montfleury, Tunis, Tunisia).

\section{Declarations}

Ethics approval and consent to participate: Not applicable.

Consent for publication: The copyright permissions have been taken and consent to submit has been received explicitly from all co-authors.

Competing interests: The authors declare no competing interests.

\section{References}

[1] S. Malkin, Y. Koren, A. Ber, Off-Line Grinding Optimization with a Micro-Computer, CIRP Ann. - Manuf. Technol. 29 (1980) 213-216. doi:10.1016/S0007-8506(07)61324-9.

[2] S. Paul, A.B. Chattopadhyay, Effects of cryogenic cooling by liquid nitrogen jet on forces, temperature and surface residual stresses in grinding steels, Cryogenics (Guildf). 35 (1995) 515-523. doi:10.1016/0011-2275(95)98219-Q.

[3] B. Ben Fathallah, N. Ben Fredj, H. Sidhom, C. Braham, Y. Ichida, Effects of abrasive type cooling mode and peripheral grinding wheel speed on the AISI D2 steel ground surface integrity, Int. J. Mach. Tools Manuf. 49 (2009) 261-272. 
doi:10.1016/j.ijmachtools.2008.10.005.

[4] S. Paul, A.B. Chattopadhyay, The effect of cryogenic cooling on grinding forces, Int. J. Mach. Tools Manuf. 36 (1996) 63-72. doi:10.1016/0890-6955(95)92629-D.

[5] S. Malkin, C. Guo, Thermal Analysis of Grinding, CIRP Ann. - Manuf. Technol. 56 (2007) 760-782. doi:10.1016/j.cirp.2007.10.005.

[6] H.K. Tönshoff, J. Peters, I. Inasaki, T. Paul, Modelling and Simulation of Grinding Processes, CIRP Ann. - Manuf. Technol. 41 (1992) 677-688. doi:10.1016/S00078506(07)63254-5.

[7] B. Ben Fathallah, C. Braham, H. Sidhom, Combined effects of abrasive type and cooling mode on fatigue resistance of AISI D2 ground surface, Int. J. Fatigue. (2020) 105665. doi:10.1016/j.ijfatigue.2020.105665.

[8] A. Laamouri, H. Sidhom, C. Braham, Evaluation of residual stress relaxation and its effect on fatigue strength of AISI 316L stainless steel ground surfaces: Experimental and numerical approaches, Int. J. Fatigue. 48 (2013) 109-121. doi:10.1016/j.ijfatigue.2012.10.008.

[9] A. Laamouri, F. Ghanem, C. Braham, H. Sidhom, Influences of up-milling and downmilling on surface integrity and fatigue strength of X160CrMoV12 steel, Int. J. Adv. Manuf. Technol. 105 (2019) 1209-1228. doi:10.1007/s00170-019-04280-2.

[10] S. Malkin, T.W. Hwang, Grinding Mechanisms for Ceramics, CIRP Ann. - Manuf. Technol. 45 (1996) 569-580. doi:10.1016/S0007-8506(07)60511-3.

[11] T. Tawakoli, M.J. Hadad, M.H. Sadeghi, A. Daneshi, S. Stöckert, A. Rasifard, An experimental investigation of the effects of workpiece and grinding parameters on minimum quantity lubrication-MQL grinding, Int. J. Mach. Tools Manuf. 49 (2009) 924 932. doi:10.1016/j.ijmachtools.2009.06.015.

[12] B. Ben Fathallah, C.E. Dakhli, M.A. Terres, The effect of grinding parameters and gas nitriding depth on the grindability and surface integrity of AISI D2 tool steel, Int. J. Adv. Manuf. Technol. 104 (2019) 1449-1459. doi:10.1007/s00170-019-03943-4.

[13] E. Brinksmeier, J.C. Aurich, E. Govekar, C. Heinzel, H.W. Hoffmeister, F. Klocke, J. Peters, R. Rentsch, D.J. Stephenson, E. Uhlmann, K. Weinert, M. Wittmann, Advances in modeling and simulation of grinding processes, CIRP Ann. - Manuf. Technol. 55 (2006) 667-696. doi:10.1016/j.cirp.2006.10.003.

[14] D.A. Doman, A. Warkentin, R. Bauer, Finite element modeling approaches in grinding, Int. J. Mach. Tools Manuf. 49 (2009) 109-116. doi:10.1016/j.ijmachtools.2008.10.002.

[15] W.B. Rowe, M.N. Morgan, D.A. Allanson, An Advance in the Modelling of Thermal Effects in the Grinding Process, CIRP Ann. - Manuf. Technol. 40 (1991) 339-342. doi:10.1016/S0007-8506(07)62001-0.

[16] S. Belhadi, T. Mabrouki, J.F. Rigal, L. Boulanouar, Experimental and numerical study of chip formation during straight turning of hardened AISI 4340 steel, Proc. Inst. Mech. Eng. Part B J. Eng. Manuf. 219 (2005) 515-524. doi:10.1243/095440505X32445.

[17] M. Asad, H. Ijaz, W. Saleem, A. Mahfouz, Z. Ahmad, T. Mabrouki, Finite Element Analysis and Statistical Optimization of End-Burr in Turning AA2024, Metals (Basel). 9 (2019) 276. doi:10.3390/met9030276.

[18] A. Brosse, H. Hamdi, J. Bergheau, Residual stresses prediction with a new thermo mechanical simulation of grinding, Int. J. Mater. Form. 1 (2008) 1319-1322. doi:10.1007/s12289-008-0146-5. 
[19] F. Ghanem, N. Ben Fredj, H. Sidhom, C. Braham, Effects of finishing processes on the fatigue life improvements of electro-machined surfaces of tool steel, Int. J. Adv. Manuf. Technol. 52 (2011) 583-595. doi:10.1007/s00170-010-2751-y.

[20] K. Makhlouf, N. Sidhom, A. Khlifi, H. Sidhom, C. Braham, Low cycle fatigue life improvement of AISI 304 by initial and intermittent wire brush hammering, Mater. Des. 52 (2013) 1088-1098. doi:10.1016/j.matdes.2013.06.065.

[21] H. Hamdi, H. Zahouani, J.M. Bergheau, Residual stresses computation in a grinding process, J. Mater. Process. Technol. 147 (2004) 277-285. doi:10.1016/S09240136(03)00578-8.

[22] T. Mabrouki, J.F. Rigal, A contribution to a qualitative understanding of thermomechanical effects during chip formation in hard turning, J. Mater. Process. Technol. 176 (2006) 214-221. doi:10.1016/j.jmatprotec.2006.03.159.

[23] W.S. Lau, M. Wang, W.B. Lee, A simple method of eliminating residual tensile stresses in the grinding of low carbon steels, Int. J. Mach. Tools Manuf. (1991). doi:10.1016/08906955(91)90087-J.

[24] L.R. da Silva, E.C. Bianchi, R.Y. Fusse, R.E. Catai, T.V. França, P.R. Aguiar, Analysis of surface integrity for minimum quantity lubricant-MQL in grinding, Int. J. Mach. Tools Manuf. 47 (2007) 412-418. doi:10.1016/j.ijmachtools.2006.03.015.

[25] A. Ghosh, A.K. Chattopadhyay, Experimental investigation on performance of touchdressed single-layer brazed cBN wheels, Int. J. Mach. Tools Manuf. 47 (2007) 1206-1213. doi:10.1016/j.ijmachtools.2006.08.020.

[26] M.J. Jackson, C.J. Davis, M.P. Hitchiner, B. Mills, High-speed grinding with CBN grinding wheels - applications and future technology, J. Mater. Process. Technol. 110 (2001) 78-88. doi:10.1016/S0924-0136(00)00869-4.

[27] K.S. Murthy, I. Rajendran, A study on optimisation of cutting parameters and prediction of surface roughness in end milling of aluminium under MQL machining, Int. J. Mach. Mach. Mater. 7 (2010) 112-128. doi:10.1504/IJMMM.2010.029849.

[28] S. Paul, A.B. Chattopadhyay, A study of effects of cryo-cooling in grinding, Int. J. Mach. Tools Manuf. 35 (1995) 109-117. doi:10.1016/0890-6955(95)80010-7.

[29] N. Ben Fredj, H. Sidhom, C. Braham, Ground surface improvement of the austenitic stainless steel AISI 304 using cryogenic cooling, Surf. Coatings Technol. 200 (2006) 48464860. doi:10.1016/j.surfcoat.2005.04.050.

[30] C.J. Tzeng, Y.H. Lin, Y.K. Yang, M.C. Jeng, Optimization of turning operations with multiple performance characteristics using the Taguchi method and Grey relational analysis, J. Mater. Process. Technol. 209 (2009) 2753-2759. doi:10.1016/j.jmatprotec.2008.06.046.

[31] S. Anurag, Y. Guo, Predictive model to decouple the contributions of friction and plastic deformation to machined surface temperatures and residual stress patterns in finish dry cutting, Front. Mech. Eng. China. 5 (2010) 247-255. doi:10.1007/s11465-010-0097-7.

[32] A. Lefebvre, P. Vieville, P. Lipinski, C. Lescalier, Numerical analysis of grinding temperature measurement by the foil/workpiece thermocouple method, Int. J. Mach. Tools Manuf. 46 (2006) 1716-1726. doi:10.1016/j.ijmachtools.2005.12.009.

[33] D.J. Stephenson, T. Jin, J. Corbett, High efficiency deep grinding of a low alloy steel with plated CBN wheels, CIRP Ann. - Manuf. Technol. 51 (2002) 241-244. doi:10.1016/S00078506(07)61508-X. 
[34] N. Ben Fredj, M. Ben Nasr, A. Ben Rhouma, C. Braham, H. Sidhom, Fatigue life improvements of the AISI 304 stainless steel ground surfaces by wire brushing, J. Mater. Eng. Perform. 13 (2004) 564-574. doi:10.1361/15477020420819.

[35] Y. Ohbuchi, T. Matsuo, Force and Chip Formation in Single-Grit Orthogonal Cutting with Shaped CBN and Diamond Grains, CIRP Ann. - Manuf. Technol. 40 (1991) 327-330. doi:10.1016/S0007-8506(07)61998-2.

[36] H. Sidhom, N. Ben Moussa, B. Ben Fathallah, N. Sidhom, C. Braham, Effect of surface properties on the fatigue life of manufactured parts: Experimental analysis and multi-axial criteria, 2014. doi:10.4028/www.scientific.net/AMR.996.715.

[37] A. Ben Rhouma, N. Sidhom, K. Makhlouf, H. Sidhom, C. Braham, G. Gonzalez, Effect of machining processes on the residual stress distribution heterogeneities and their consequences on the stress corrosion cracking resistance of AISI 316L SS in chloride medium, Int. J. Adv. Manuf. Technol. 105 (2019) 1699-1711. doi:10.1007/s00170-01904410-w.

[38] A. Yui, H.S. Lee, Surface grinding with ultra high speed CBN wheel, J. Mater. Process. Technol. 62 (1996) 393-396. doi:10.1016/S0924-0136(96)02441-7.

[39] J.K.N. Murthy, A.B. Chattopadhyay, A.K. Chakrabarti, Studies on the grindability of some alloy steels, J. Mater. Process. Technol. 104 (2000) 59-66. doi:10.1016/S09240136(00)00516-1.

[40] G.R. Johnson, W.H. Cook, Fracture characteristics of three metals subjected to various strains, strain rates, temperatures and pressures, Eng. Fract. Mech. 21 (1985) 31-48. doi:10.1016/0013-7944(85)90052-9.

[41] K. Li, X.L. Gao, J.W. Sutherland, Finite element simulation of the orthogonal metal cutting process for qualitative understanding of the effects of crater wear on the chip formation process, J. Mater. Process. Technol. 127 (2002) 309-324. doi:10.1016/S09240136(02)00281-9.

[42] P.M. T.H. Lee, Experimental and theoretical investigation of AISI D2 hardened steel machining with varying nose radius CBN tools | International Journal of Machining and Machinability of Materials, (2007). https://www.inderscienceonline.com/doi/pdf/10.1504/IJMMM.2007.013787 (accessed August 20, 2020).

[43] C.E. Becze, M.A. Elbestawi, A chip formation based analytic force model for oblique cutting, Int. J. Mach. Tools Manuf. 42 (2002) 529-538. doi:10.1016/S0890-6955(01)001298.

[44] T. Özel, Y. Karpat, L. Figueira, J.P. Davim, Modelling of surface finish and tool flank wear in turning of AISI D2 steel with ceramic wiper inserts, J. Mater. Process. Technol. 189 (2007) 192-198. doi:10.1016/j.jmatprotec.2007.01.021.

[45] T.H. Lee, P. Mathew, Experimental and theoretical investigation of AISI D2 hardened steel machining with varying nose radius CBN tools, Int. J. Mach. Mach. Mater. 2 (2007) 254 269. doi:10.1504/IJMMM.2007.013787.

[46] J.-C. Tanguy, Centre technique des industries mécaniques., Rectification : connaissances de base et données pratiques, CETIM, 1985.

[47] Y. Zhejun, H. Zhonghui -Submitted, A. Kobayashi, Surface Integrity of Grinding of Bearing Steel GCr15 with CBN Wheels, n.d.

[48] S. Shaji, V. Radhakrishnan, Investigations on the application of solid lubricants in grinding, 
Proc. Inst. Mech. Eng. Part B J. Eng. Manuf. 216 (2002) 1325-1343.

doi:10.1243/095440502320405421.

[49] L.R. Silva, E.C. Bianchi, R.E. Catai, R.Y. Fusse, T. V. França, P.R. Aguiar, Study on the behavior of the Minimum quantity lubricant - MQL technique under different lubricating and cooling conditions when grinding ABNT 4340 steel, J. Brazilian Soc. Mech. Sci. Eng. 27 (2005) 192-199. doi:10.1590/S1678-58782005000200012.

[50] T. Nguyen, L.C. Zhang, Grindinghardening using dry air and liquid nitrogen: Prediction and verification of temperature fields and hardened layer thickness, Int. J. Mach. Tools Manuf. 50 (2010) 901-910. doi:10.1016/j.ijmachtools.2010.06.002. 


\section{Tables list}

Table 1 The constants of the Johnson \& Cook equation of AISI D2 steel established by [43-45].

Table 2 Mechanical and thermo physical characteristics of AISI D2 tool steel $[42,43]$.

Table 3 Computation of heat flow values $\left(\varphi_{p}\right)$ transmitted to the workpiece for combinations $(\mathrm{A}-\mathrm{C}-\mathrm{Cd})\left(\mathrm{v}_{\mathrm{s}}=22 \mathrm{~m} / \mathrm{s}, \mathrm{v}_{\mathrm{w}}=0.15 \mathrm{~m} / \mathrm{s}\right)$.

Table 4 Reference of ground surface combinations of test specimens.

Table 5 Effect of combinations grinding parameters (A-C-Cd) of AISI D2 tool steel on the maximum temperatures and surface residual stresses $\left(\sigma_{00}^{S}, \sigma_{90}^{S}\right)$ with computational simulation.

Table 6 Validation of numerical simulation data on maximum surface temperatures induced by different combinations (A-C-Cd) of grinding AISI D2 tool steel. 
Fig. 1 Numerical approach of the predictive accuracy of surface grinding temperature and the residual stress.

Fig. 2 Typical experimental stress-strain curves obtained from the high strain rate tests: shear stress to plastic strain of AISI D2 tool steel as a function of initial test temperature [43]

Fig. 3 Grinding modelisation workpiece of AISI D2 tool steel.

Fig. 4 Spatial discretisation of the specimen geometry.

Fig. 5. Temperature gradient: effect of depth of cut on the AISI D2 tool steel $\left(\mathrm{v}_{\mathrm{w}}=0.15 \mathrm{~m} / \mathrm{s}\right.$ and $\mathrm{v}_{\mathrm{s}}=22 \mathrm{~m} / \mathrm{s}$. (a) $\mathrm{a}_{\mathrm{w}}=15 \mu \mathrm{m}$ and (b) $\mathrm{a}_{\mathrm{w}}=40 \mu \mathrm{m}$.

Fig. 6 Temperature simulation on surface and subsurface $\left(\mathrm{AL}_{2} \mathrm{O}_{3} \mathrm{CC}-\mathrm{v}_{\mathrm{w}}=0.15 \mathrm{~m} / \mathrm{s}\right.$ $1_{\mathrm{c}}=2 \mathrm{~mm}$ and $\left.\mathrm{a}_{\mathrm{w}}=40 \mu \mathrm{m}\right)$.

Fig. 7 Effect of abrasive type on temperature evolution $\left(\mathrm{v}_{\mathrm{w}}=0.15 \mathrm{~m} / \mathrm{s}-1_{\mathrm{c}}=2 \mathrm{~mm}\right.$ and $\left.\mathrm{a}_{\mathrm{w}}=30 \mu \mathrm{m}\right)$.

Fig. 8 Effect of combinations (A-C-Cd) on the grinding temperature distributions of AISI D2 tool steel. (a) Low productivity ( $\mathrm{aw}=15 \mu \mathrm{m})$ and (b) average productivity aw $=40 \mu \mathrm{m}$.

Fig. 9 Effect of combinations (A-C-Cd) on the grinding residual distributions of AISI D2 tool steel. (a) effect of abrasive type on the residual stress distributions of AISI D2 tool steel, (b) effect of the cooling mode in conventional grinding and (c) Effect of the depth of cut in conventional grinding $\left(\mathrm{a}_{\mathrm{w}}=15\right.$ and $30 \mu \mathrm{m}, \mathrm{v}_{\mathrm{s}}=22 \mathrm{~m} / \mathrm{s}$ and $\left.\mathrm{v}_{\mathrm{w}}=0.15 \mathrm{~m} / \mathrm{s}\right)$.

Fig. 10 Grinding temperature device (Constantin-iron thermocouple).

Fig. 11 Thermocouple test mounting and unfiltered tension at the ends of the thermocouple. Wheel/piece contact time. 
Fig. 12 Effect of depth of cut on temperature evolution $\left(\mathrm{v}_{\mathrm{w}}=0.15 \mathrm{~m} / \mathrm{s}-1_{\mathrm{c}}=2 \mathrm{~mm} \mathrm{Al}_{2} \mathrm{O}_{3}\right.$ abrasive type and conventional cooling mode)

Fig. 13 Numerical simulation data validation of residual stress gradients generated by different combinations (A-C-Cd) in conventional grinding $\left(\mathrm{a}_{\mathrm{w}}=30 \mu \mathrm{m}, \mathrm{v}_{\mathrm{s}}=30 \mathrm{~m} / \mathrm{s}\right.$ et $\mathrm{v}_{\mathrm{w}}=9 \mathrm{~m} / \mathrm{mn}$ ) of AISI D2 tool steel.(a) Effect of abrasive type (conventional cooling and $\mathrm{a}_{\mathrm{w}}=30 \mu \mathrm{m}$ ), (b) Effect of cooling mode (Sol gel abrasive grain and $\mathrm{a}_{\mathrm{w}}=30 \mu \mathrm{m}$ ) and (c) Effect of depth of cut $\left(\mathrm{Al}_{2} \mathrm{O}_{3}\right.$ abrasive grain and conventional cooling mode).

Fig. 14 Equivalence of effect of combination (A-C-Cc) one the microstructural softening of tool steel AISI D2.

Fig. 15 Effect of surface temperatures and contact pressure on the topography (roughness) of tool steel AISI D2 surface grinding. (a) Arithmetic roughness, Ra and (b) Total roughness, $\mathrm{Rt}$

Fig. 16 Effect of surface temperatures and contact pressure on the surface and subsurface residual stress of AISI D2 tool steel. (a) Residual stresses parallel to the grinding direction and (b)Residual stress perpendicular to the grinding direction .

Fig. 17 Effect of surface temperature on the depths of thermal affected layers and thicknesses layers to residual stresses of ground surface of AISI D2. (a) Depth of thermal affected layers and (b) thicknesses layers to residual stresses of ground surface

Fig. 18 Effect of temperature on surface integrity of AISI D2 tool steel. (a) Average length of thermal crack and (b) Thermal crack density

Fig. 19 Effect of temperature on surface productivity of AISI D2 tool 


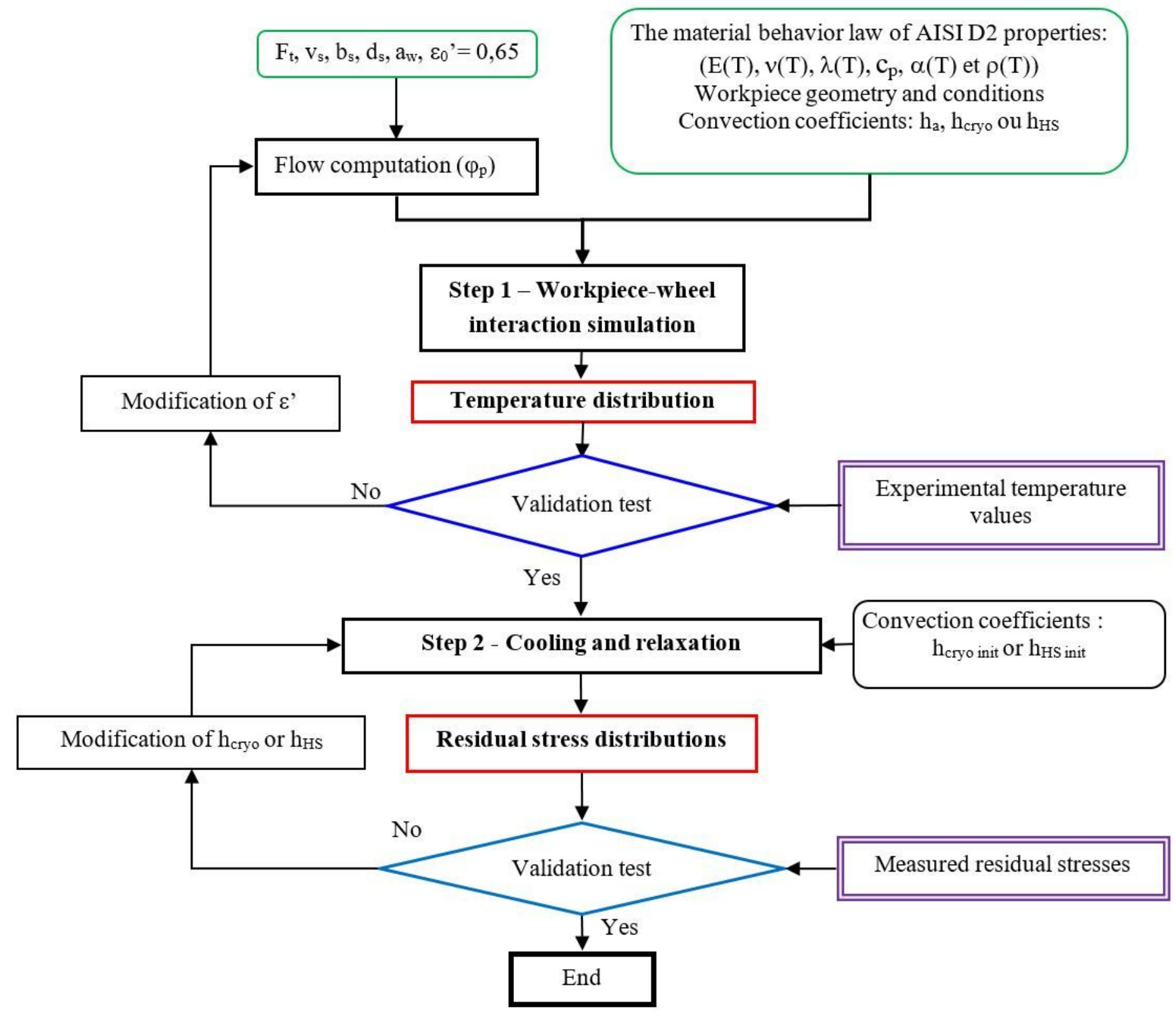

\section{Figure 1}

Numerical approach of the predictive accuracy of surface grinding temperature and the residual stress. 


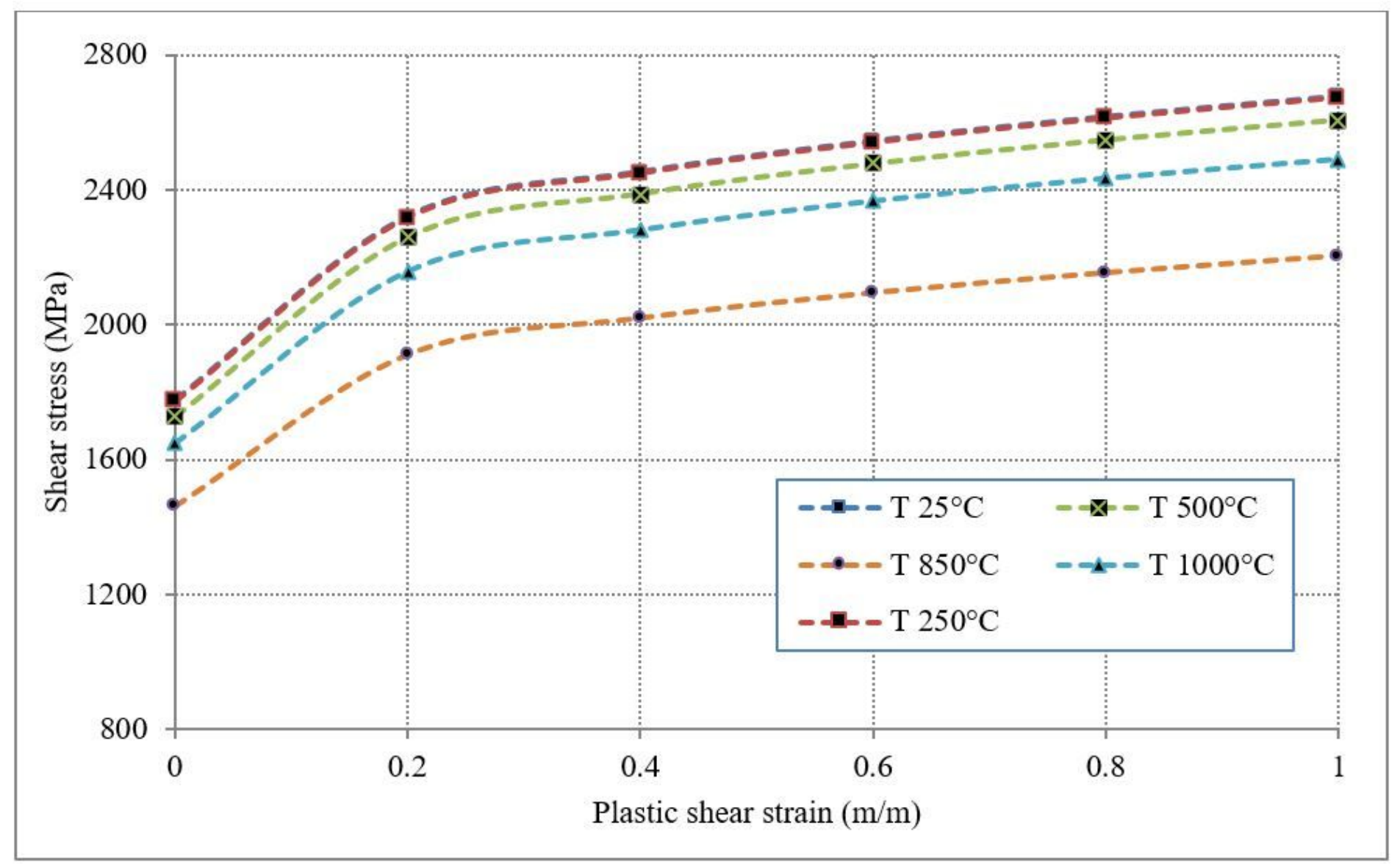

Figure 2

Typical experimental stress-strain curves obtained from the high strain rate tests: shear stress to plastic strain of AISI D2 tool steel as a function of initial test temperature [43]

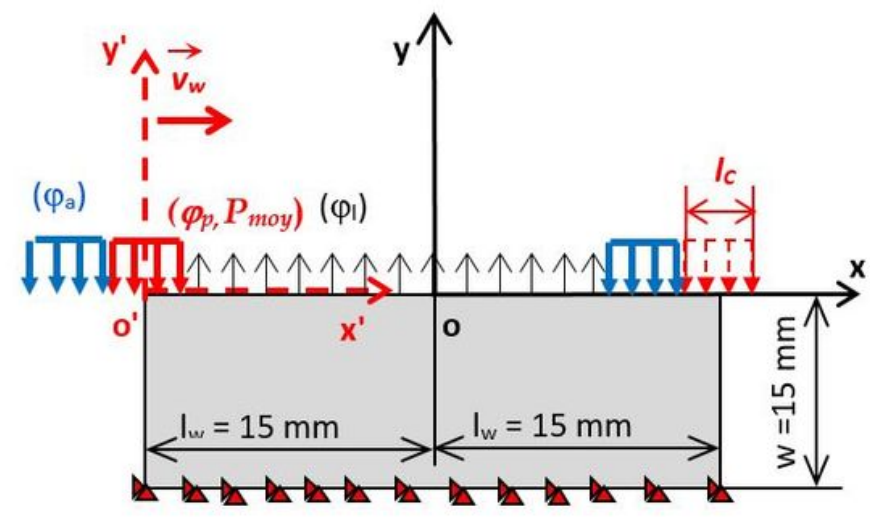

$\varphi_{\mathrm{p}}:$ heat flux transmitted to the workpiece;

$\varphi_{\mathrm{a}}$ et $\varphi_{\mathrm{I}}$ the convective flows air and lubrifiant, respectively.

$\mathbf{R}(\mathbf{o}, \overrightarrow{\mathbf{x}}, \overrightarrow{\mathbf{y}})$ : reference system linked to the workpiece.

$\mathbf{R}^{\prime}\left(\mathbf{o}^{\prime}, \overrightarrow{\mathbf{x}}^{\prime}, \overrightarrow{\mathbf{y}}^{\prime}\right)$ : reference system linked to the heat source

\section{Figure 3}

Grinding modelisation workpiece of AISI D2 tool steel. 

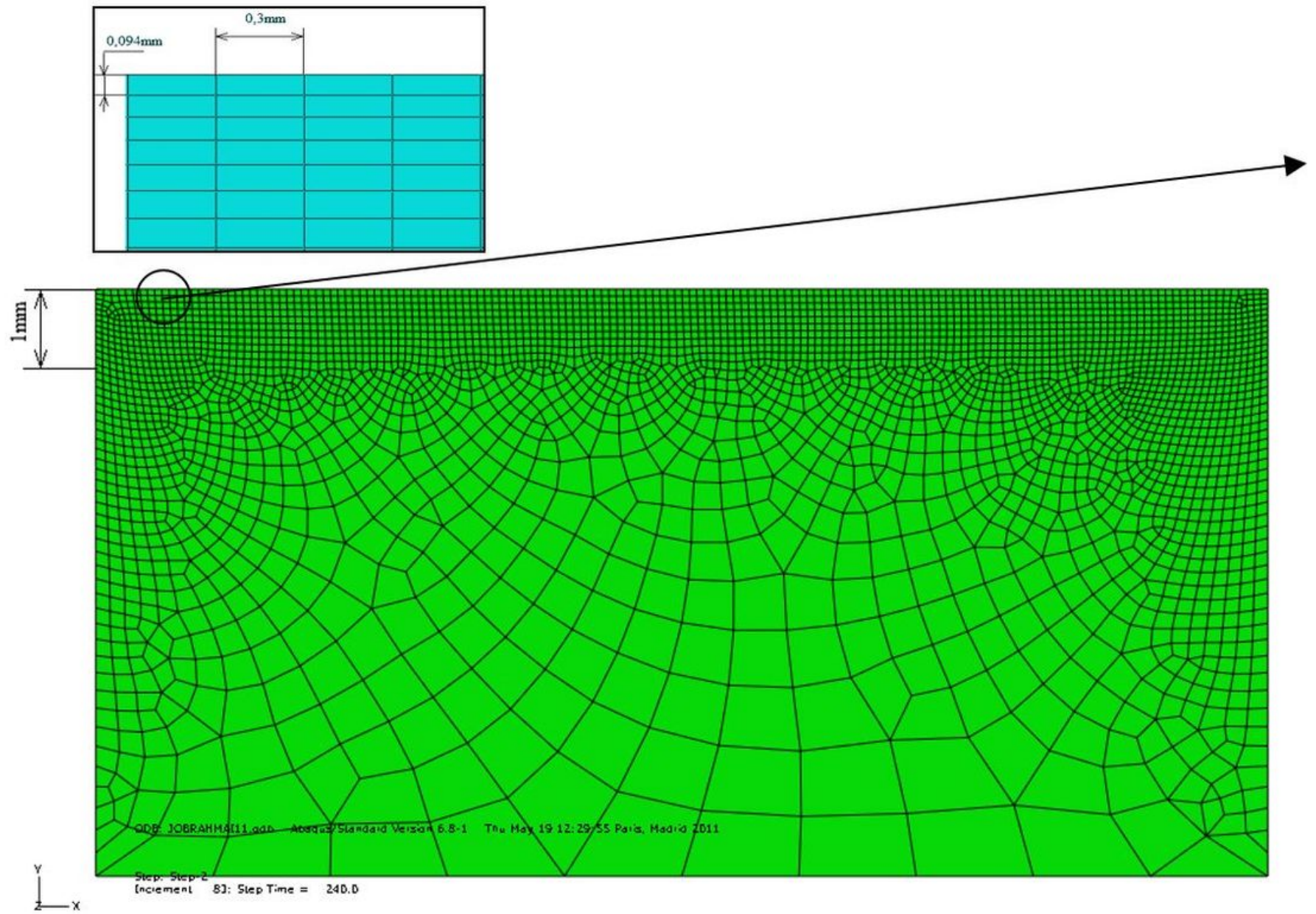

\section{Figure 4}

Spatial discretisation of the specimen geometry.

$\mathrm{AL}_{2} \mathrm{O}_{3} \mathrm{CC}$

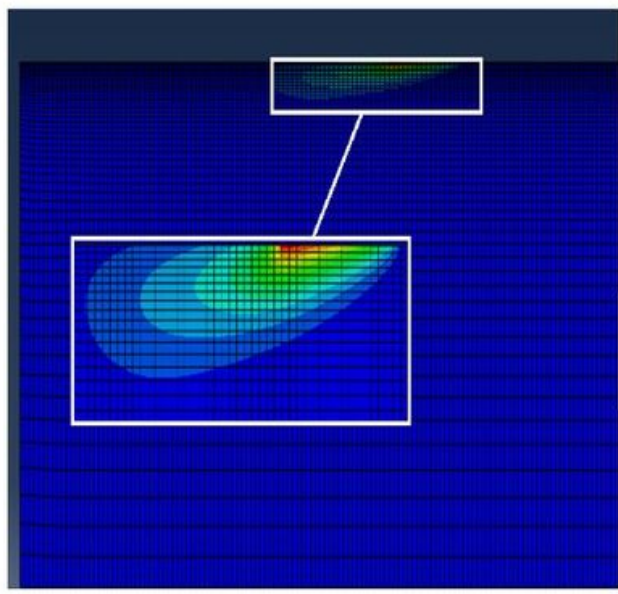

(a).
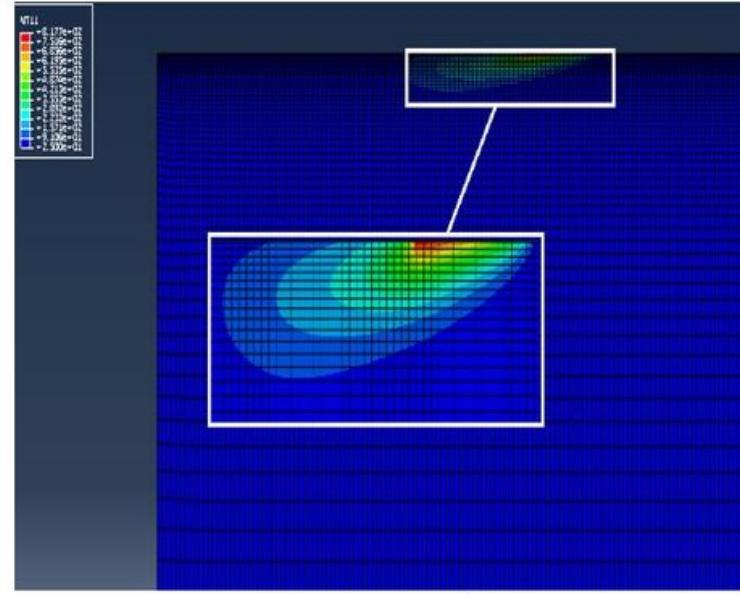

(b). 
Figure 5

Temperature gradient: effect of depth of cut on the AISI D2 tool steel $(v w=0.15 \mathrm{~m} / \mathrm{s}$ and $v s=22 \mathrm{~m} / \mathrm{s}$. (a) $\mathrm{aw}=15 \mu \mathrm{m}$ and $(\mathrm{b}) \mathrm{aw}=40 \mu \mathrm{m}$.



Figure 6

Temperature simulation on surface and subsurface (AL2O3 CC - vw $=0.15 \mathrm{~m} / \mathrm{s}-\mathrm{IC}=2 \mathrm{~mm}$ and $\mathrm{aw}=40 \mu \mathrm{m}$ ). 




Figure 7

Effect of abrasive type on temperature evolution ( $\mathrm{vw}=0.15 \mathrm{~m} / \mathrm{s}-\mathrm{Ic}=2 \mathrm{~mm}$ and $\mathrm{aw}=30 \mu \mathrm{m})$. 
(i) $\mathrm{AL}_{2} \mathrm{O}_{3} \mathrm{CC}$



(ii) SG CRYC

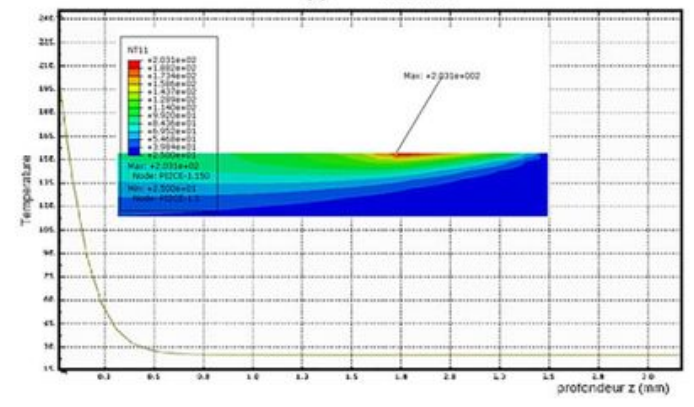

b)

(i) $\mathrm{AL}_{2} \mathrm{O}_{3} \mathrm{CC}$

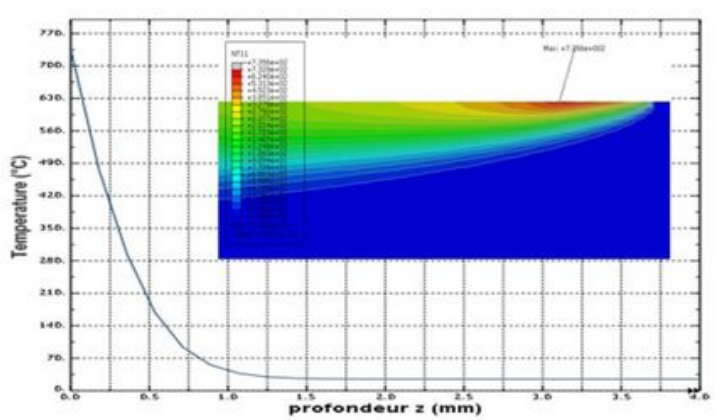

(ii) SG CRYC

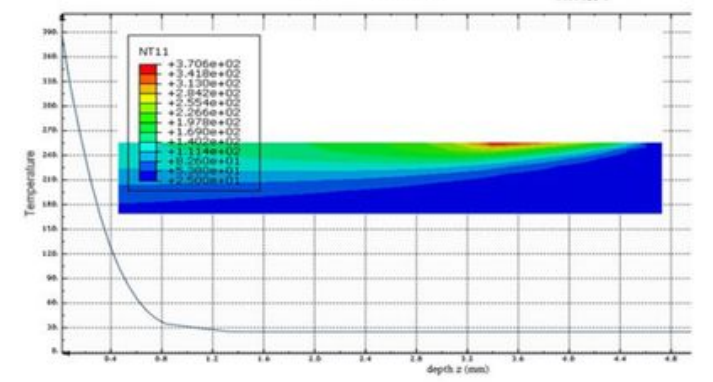

Figure 8

Effect of combinations (A-C-Cd) on the grinding temperature distributions of AISI D2 tool steel. (a) Low productivity (aw $=15 \mu \mathrm{m})$ and (b) average productivity aw $=40 \mu \mathrm{m}$. 

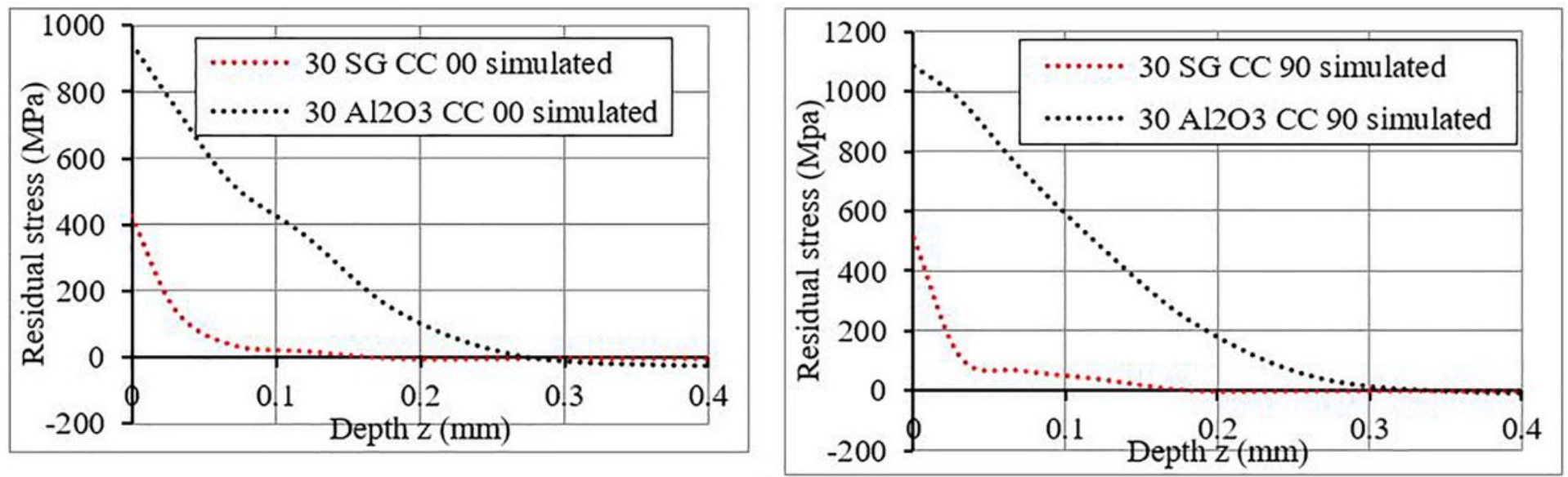

(a)

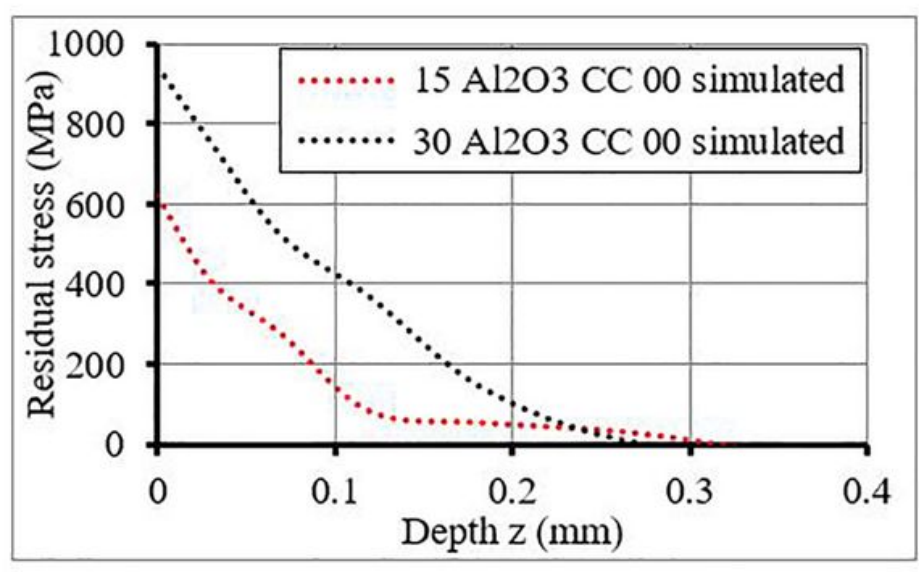

(b)

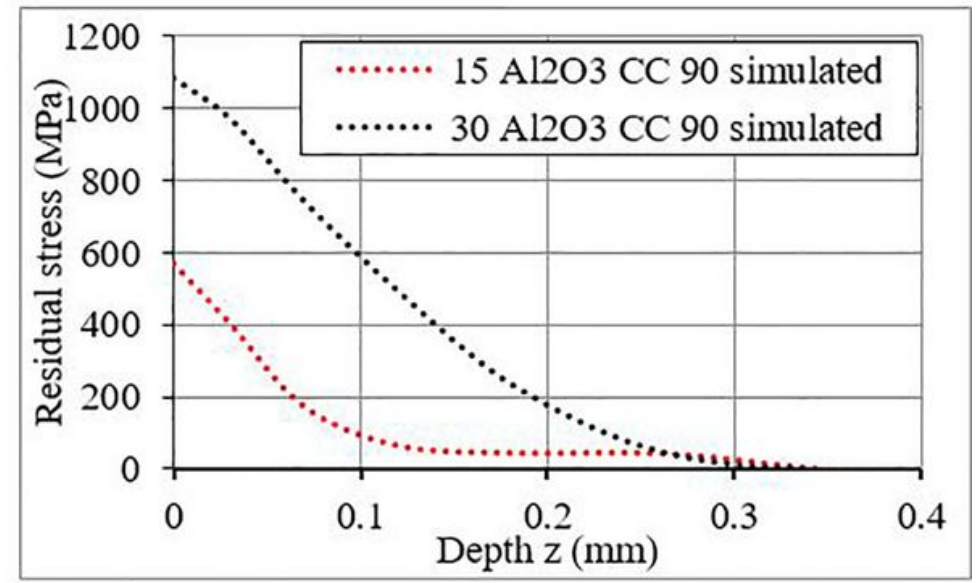

(c)

\section{Figure 9}

Effect of combinations (A-C-Cd) on the grinding residual distributions of AISI D2 tool steel. (a) effect of abrasive type on the residual stress distributions of AISI D2 tool steel, (b) effect of the cooling mode in conventional grinding and (c) Effect of the depth of cut in conventional grinding (aw $=15$ and $30 \mu \mathrm{m}$, vs = $22 \mathrm{~m} / \mathrm{s}$ and $\mathrm{vw}=0.15 \mathrm{~m} / \mathrm{s}$ ). 

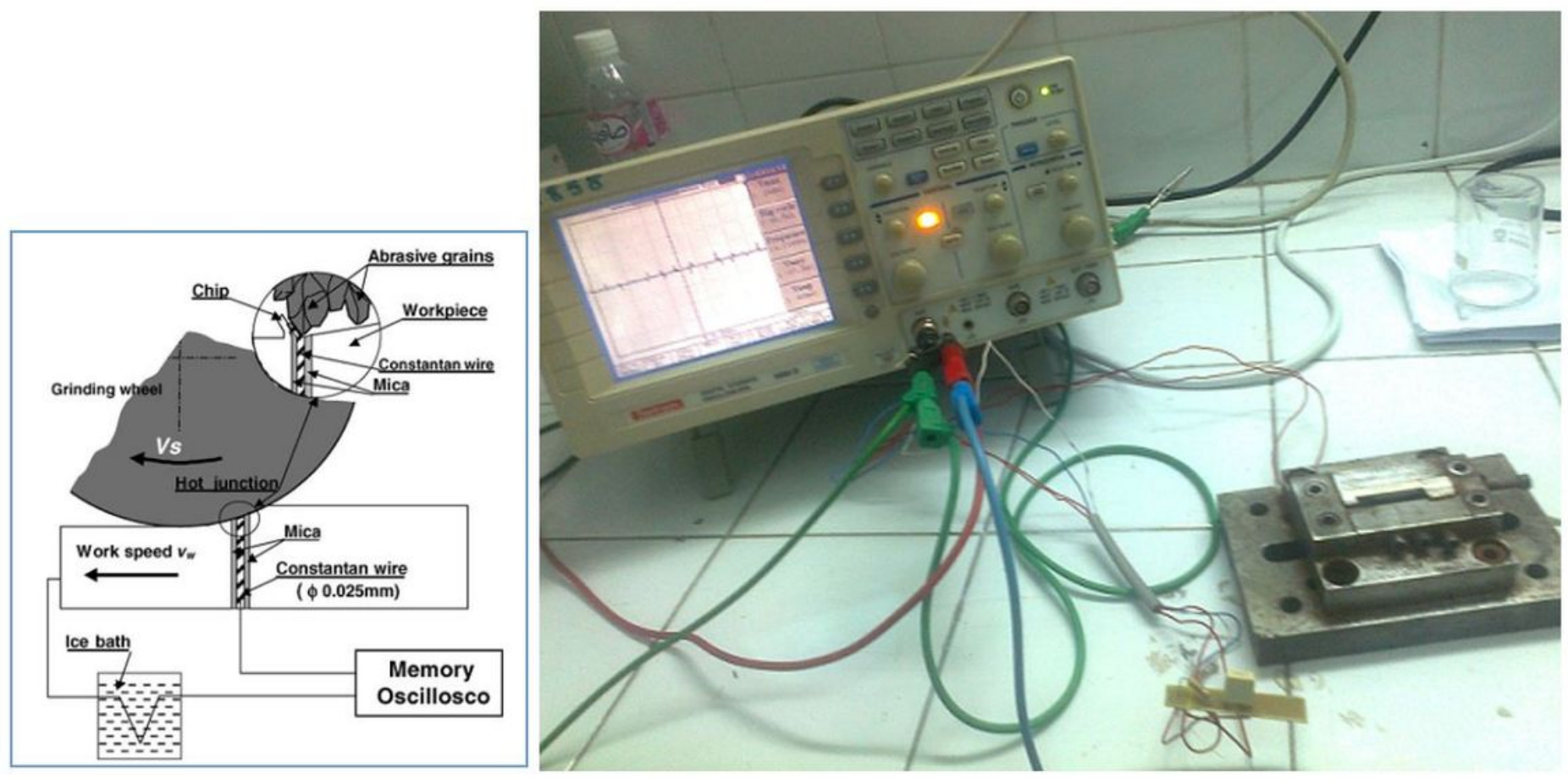

Figure 10

Grinding temperature device (Constantin-iron thermocouple).
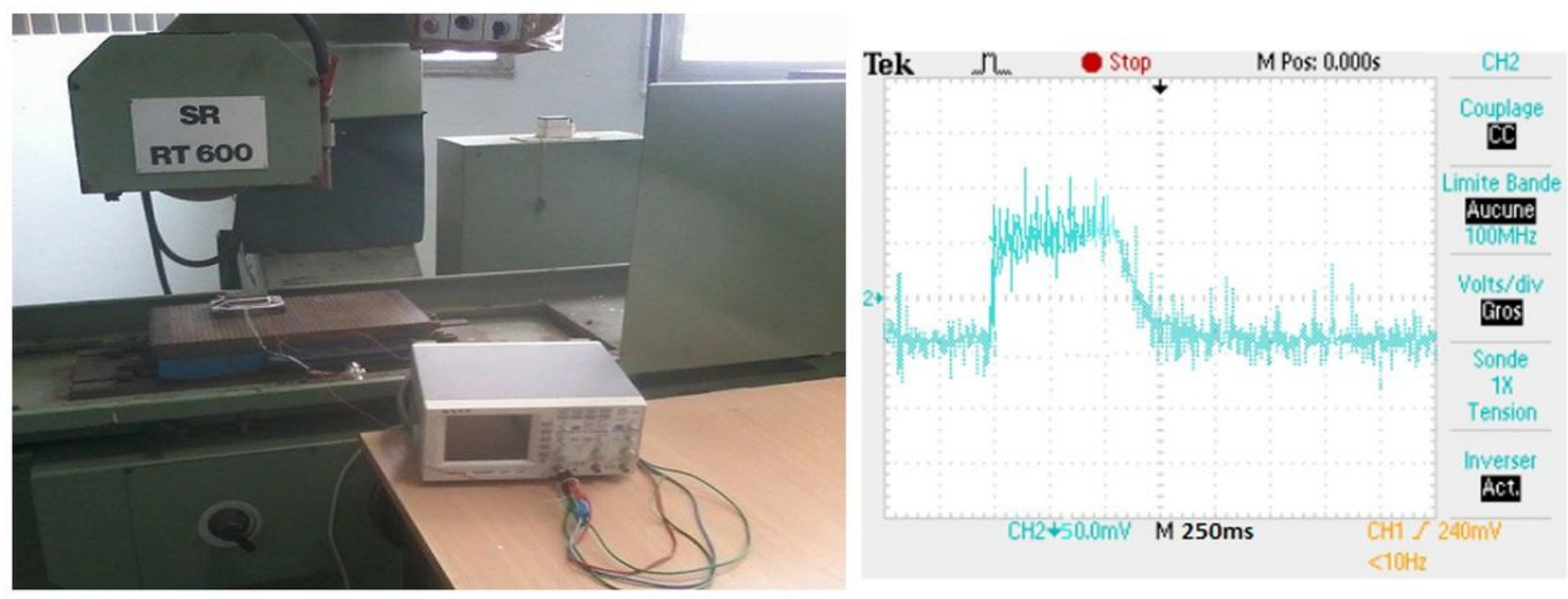

\section{Figure 11}

Thermocouple test mounting and unfiltered tension at the ends of the thermocouple. Wheel/piece contact time. 




\section{Figure 12}

Effect of depth of cut on temperature evolution ( $\mathrm{vw}=0.15 \mathrm{~m} / \mathrm{s}-\mathrm{Ic}=2 \mathrm{~mm}$ Al2O3 abrasive type and conventional cooling mode) 

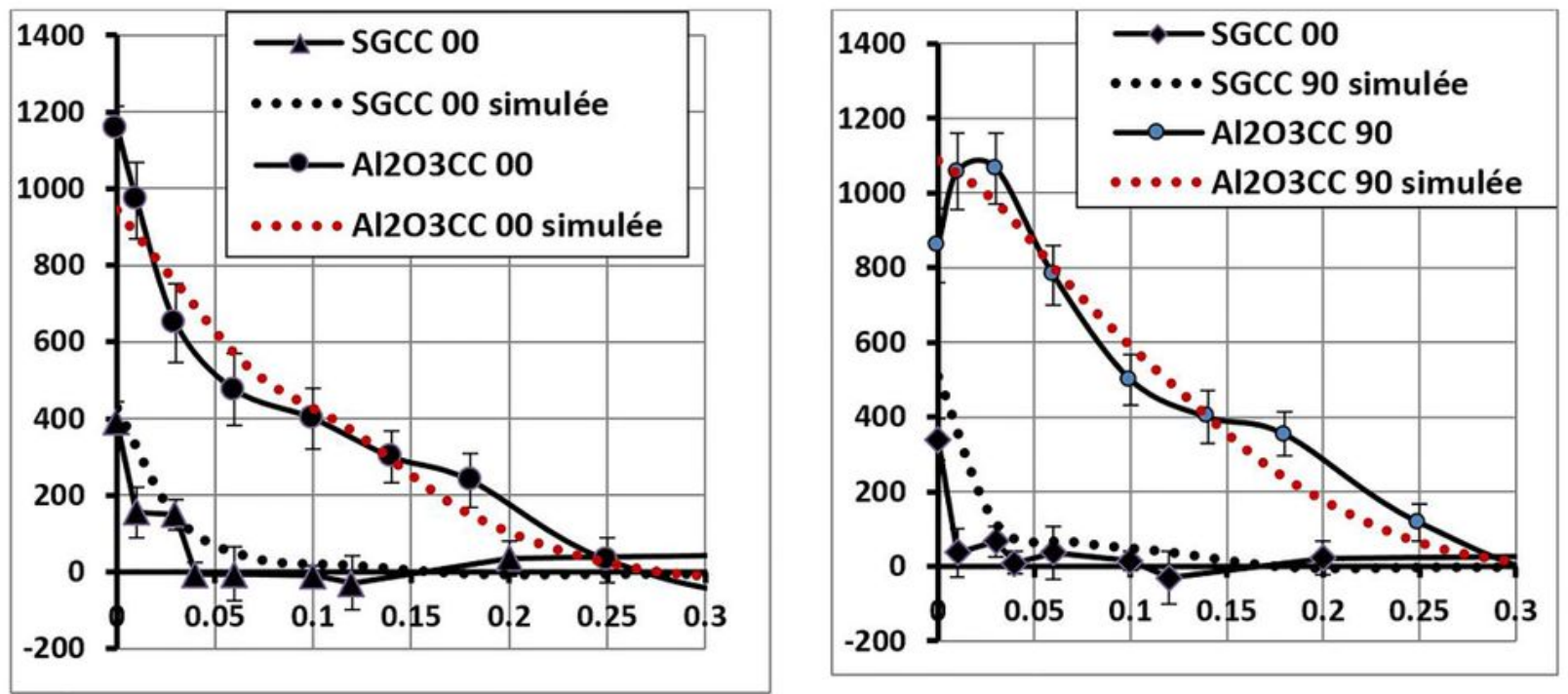

(a)
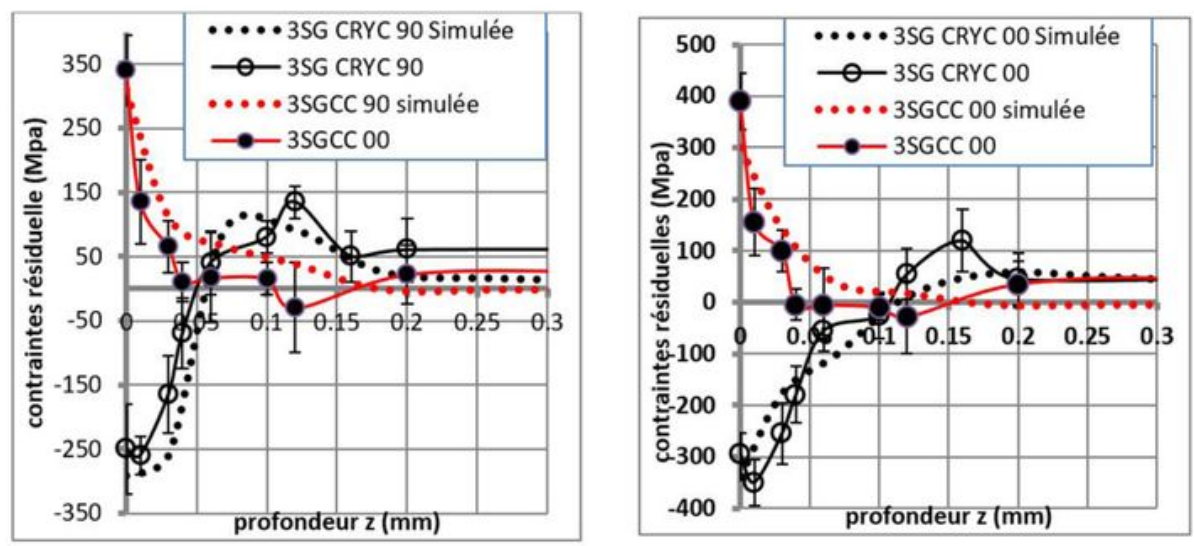

(b)
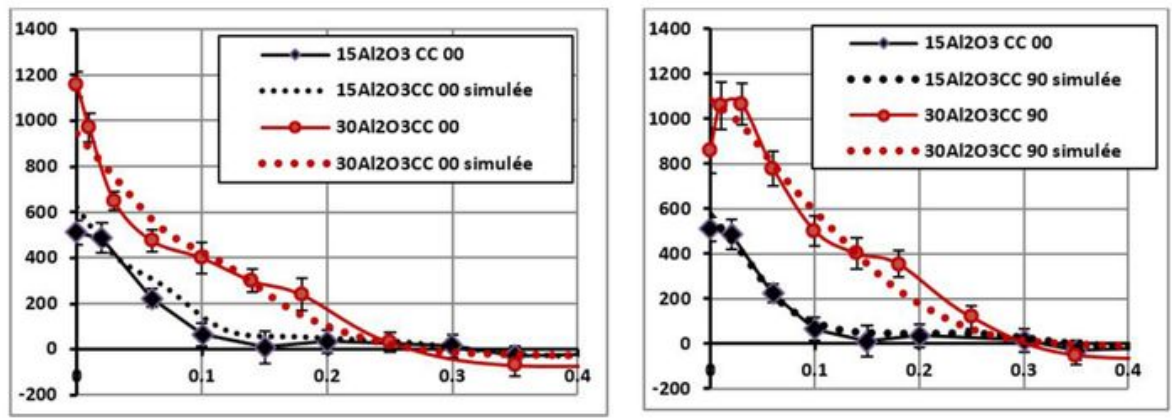

(c)

\section{Figure 13}

Numerical simulation data validation of residual stress gradients generated by different combinations (AC-Cd) in conventional grinding (aw $=30 \mu \mathrm{m}$, vs $=30 \mathrm{~m} / \mathrm{s}$ et $\mathrm{vw}=9 \mathrm{~m} / \mathrm{mn})$ of AISI D2 tool steel.(a) Effect of abrasive type (conventional cooling and aw $=30 \mu \mathrm{m}$ ), (b) Effect of cooling mode (Sol gel abrasive grain and aw $=30 \mu \mathrm{m})$ and (c) Effect of depth of cut (Al2O3 abrasive grain and conventional cooling mode). 


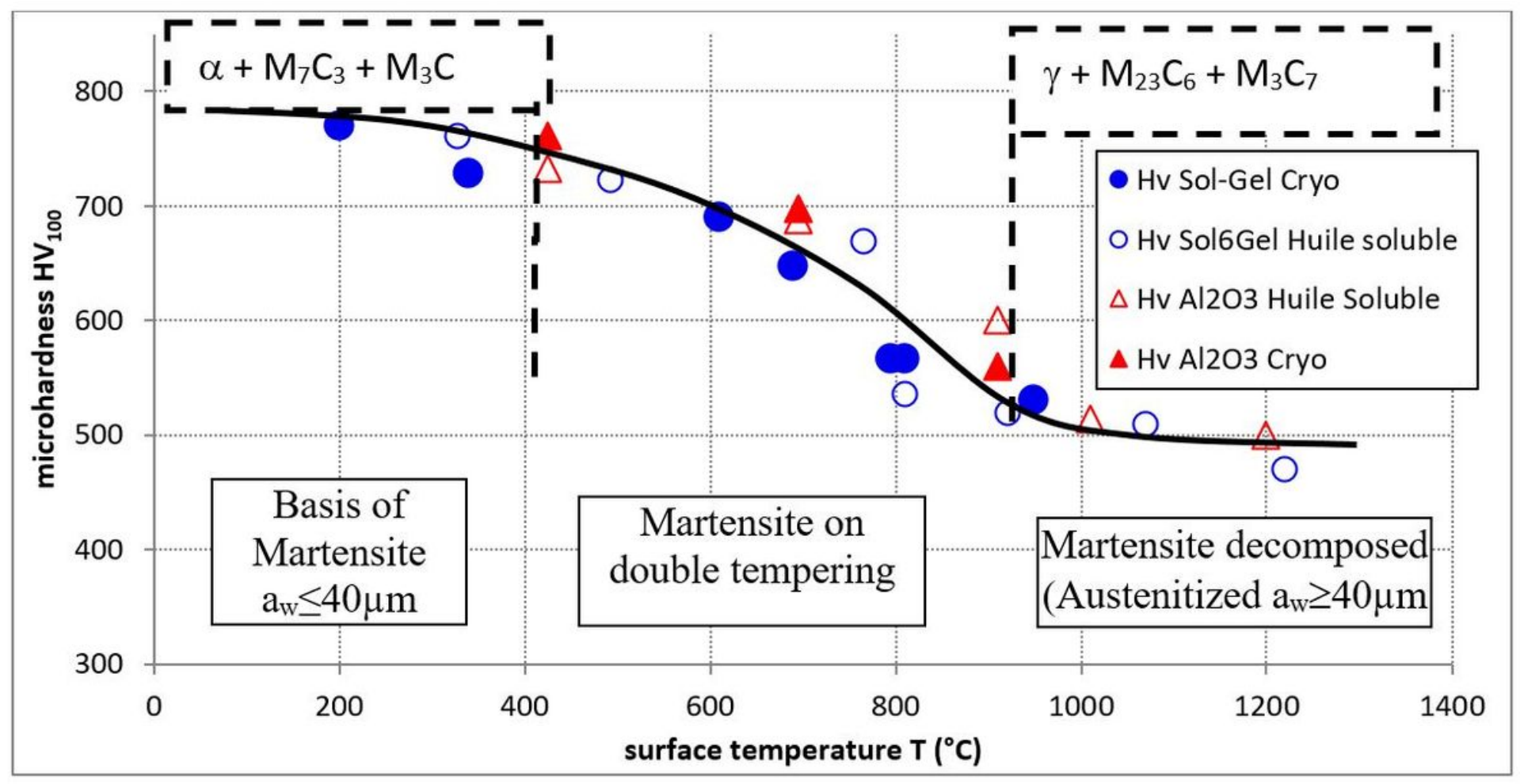

Figure 14

Equivalence of effect of combination (A-C-CC) one the microstructural softening of tool steel AISI D2. 


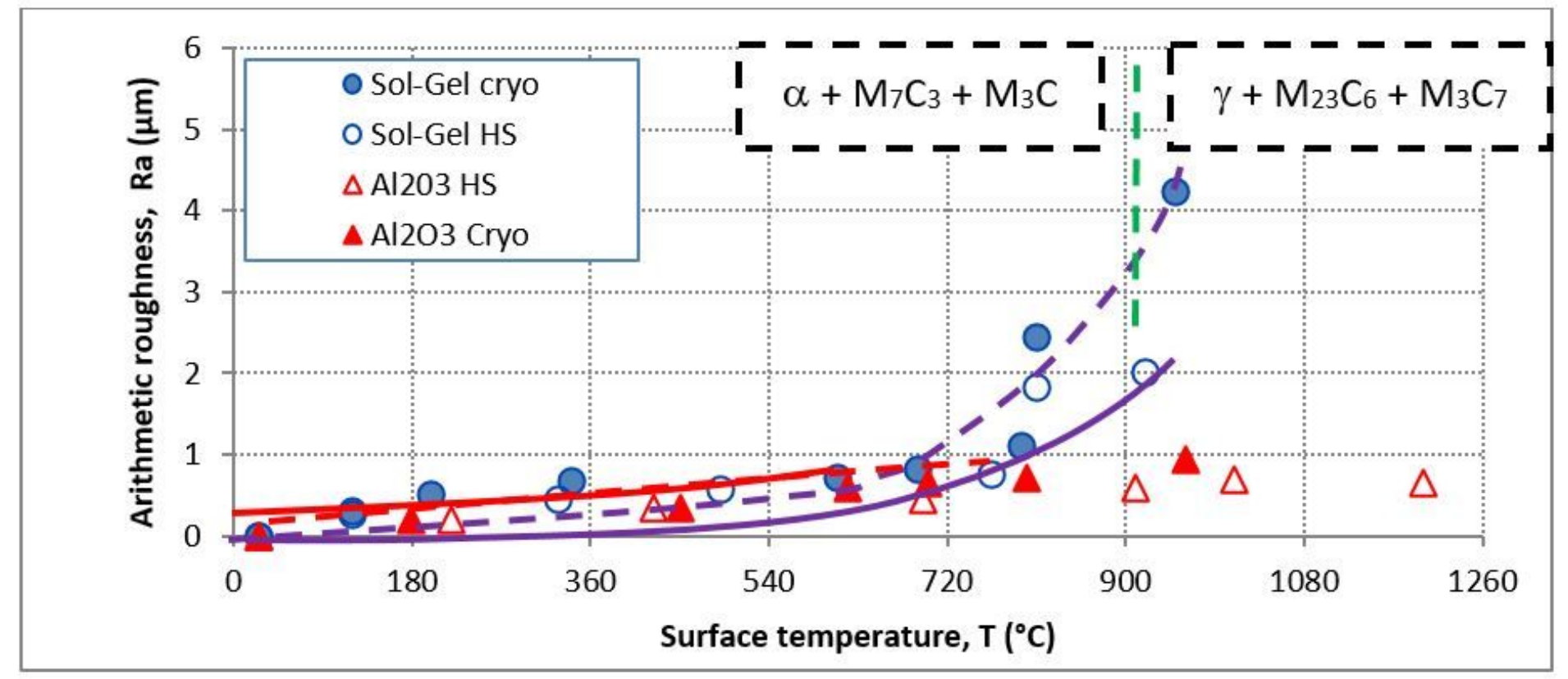

(a)



(b)

Figure 15

Effect of surface temperatures and contact pressure on the topography (roughness) of tool steel AISI D2 surface grinding. (a) Arithmetic roughness, Ra and (b) Total roughness, Rt 


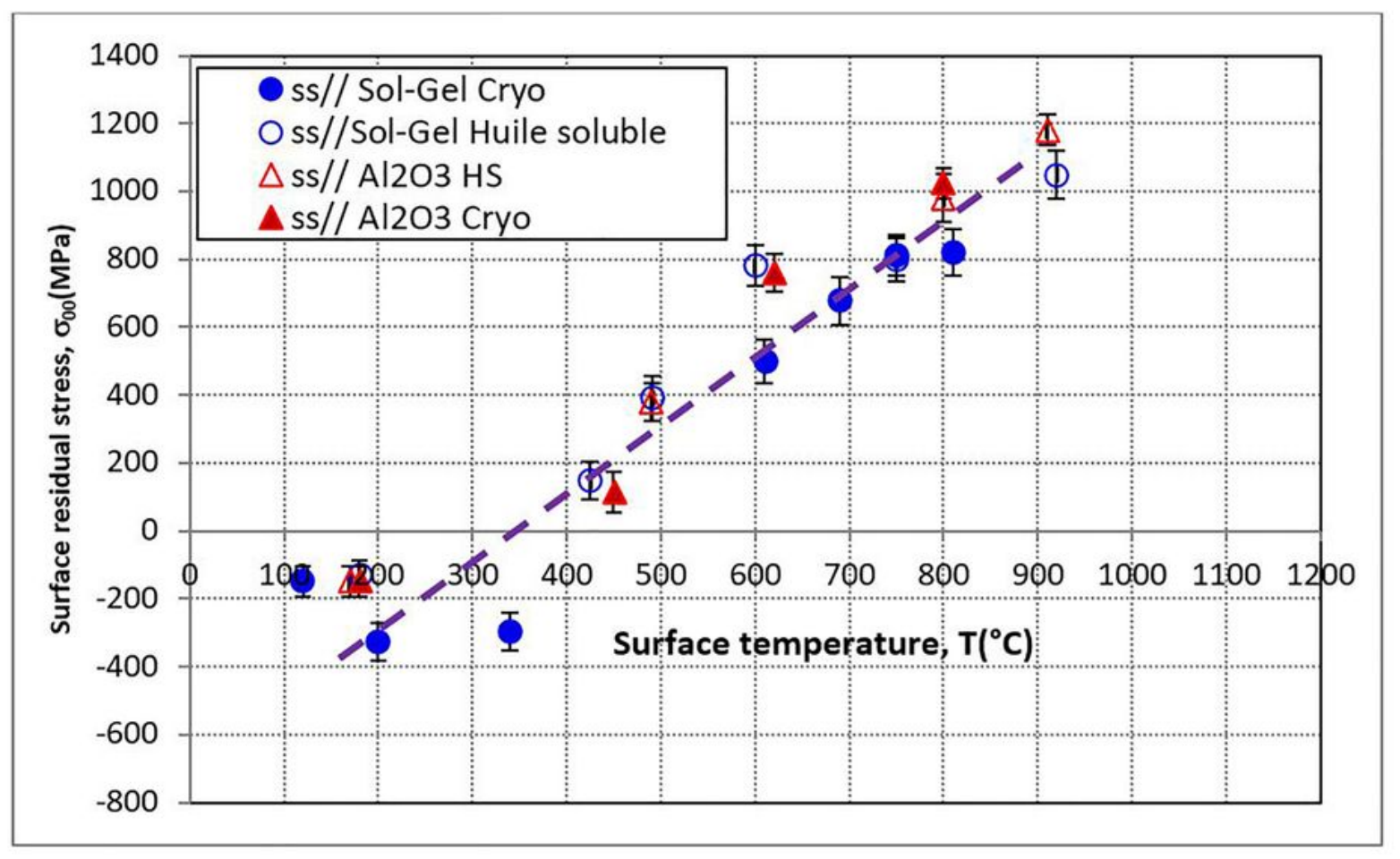

(a)

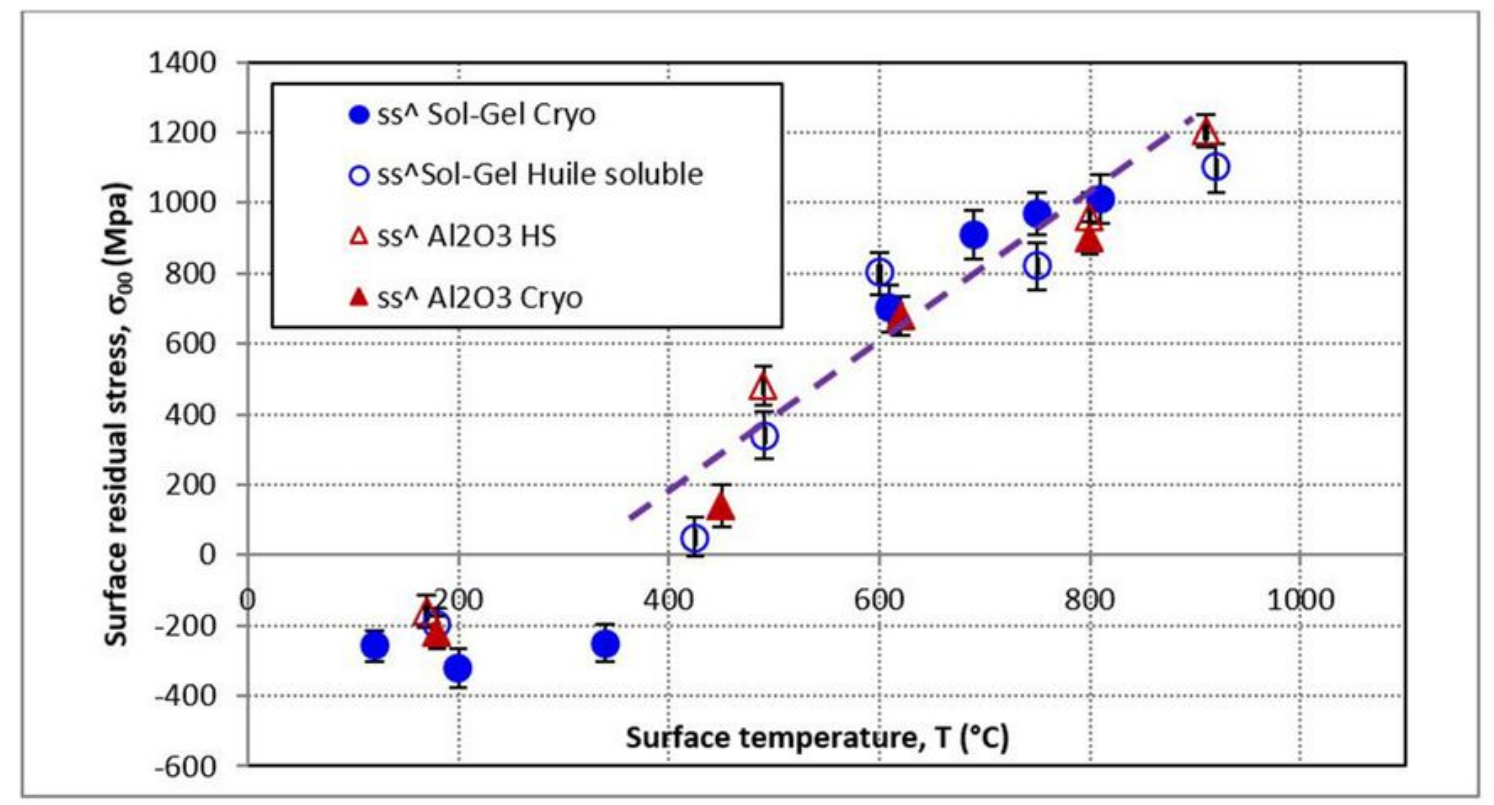

(b)

\section{Figure 16}

Effect of surface temperatures and contact pressure on the surface and subsurface residual stress of AISI D2 tool steel. (a) Residual stresses parallel to the grinding direction and (b)Residual stress perpendicular to the grinding direction . 


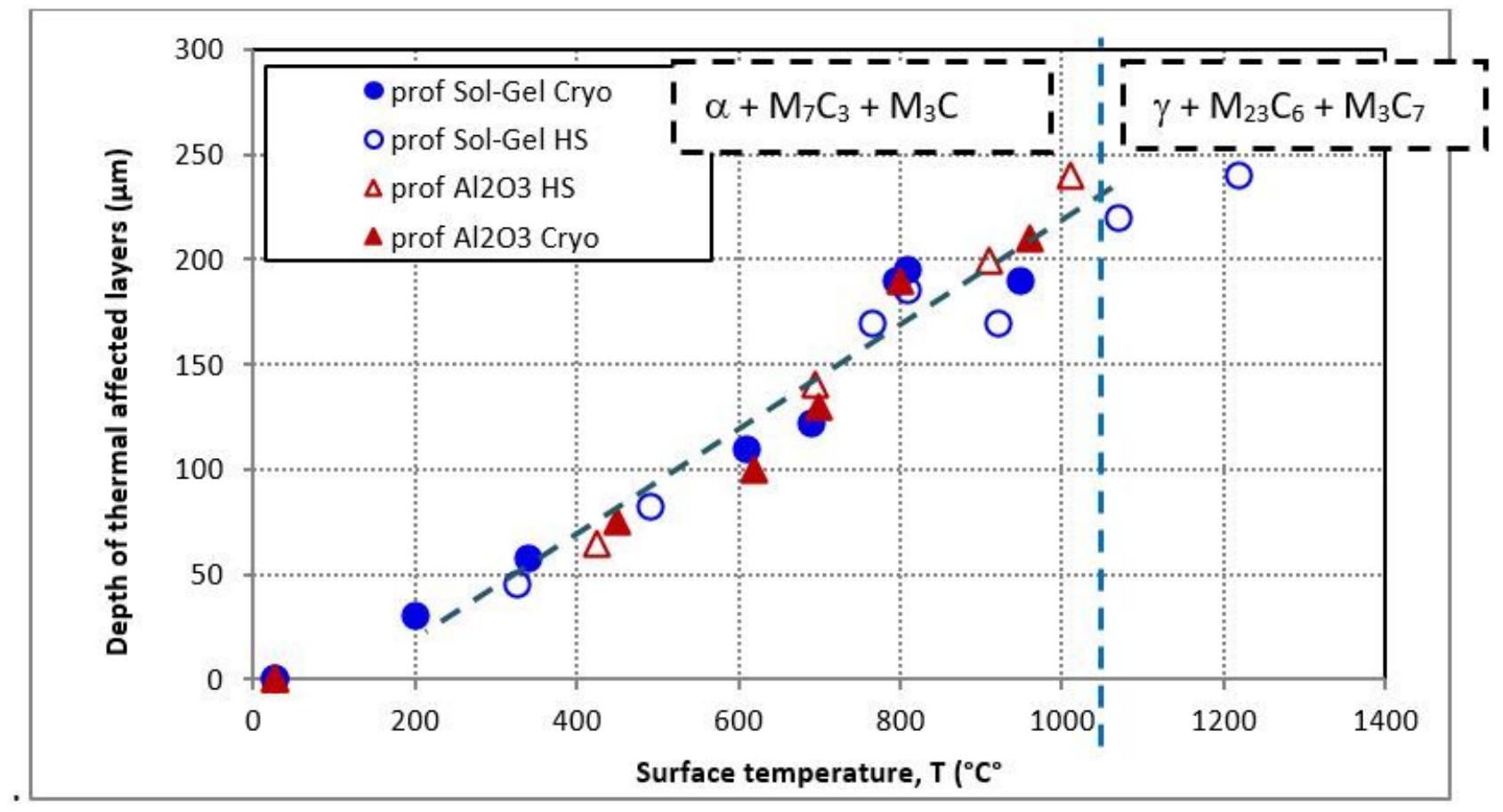

(a)

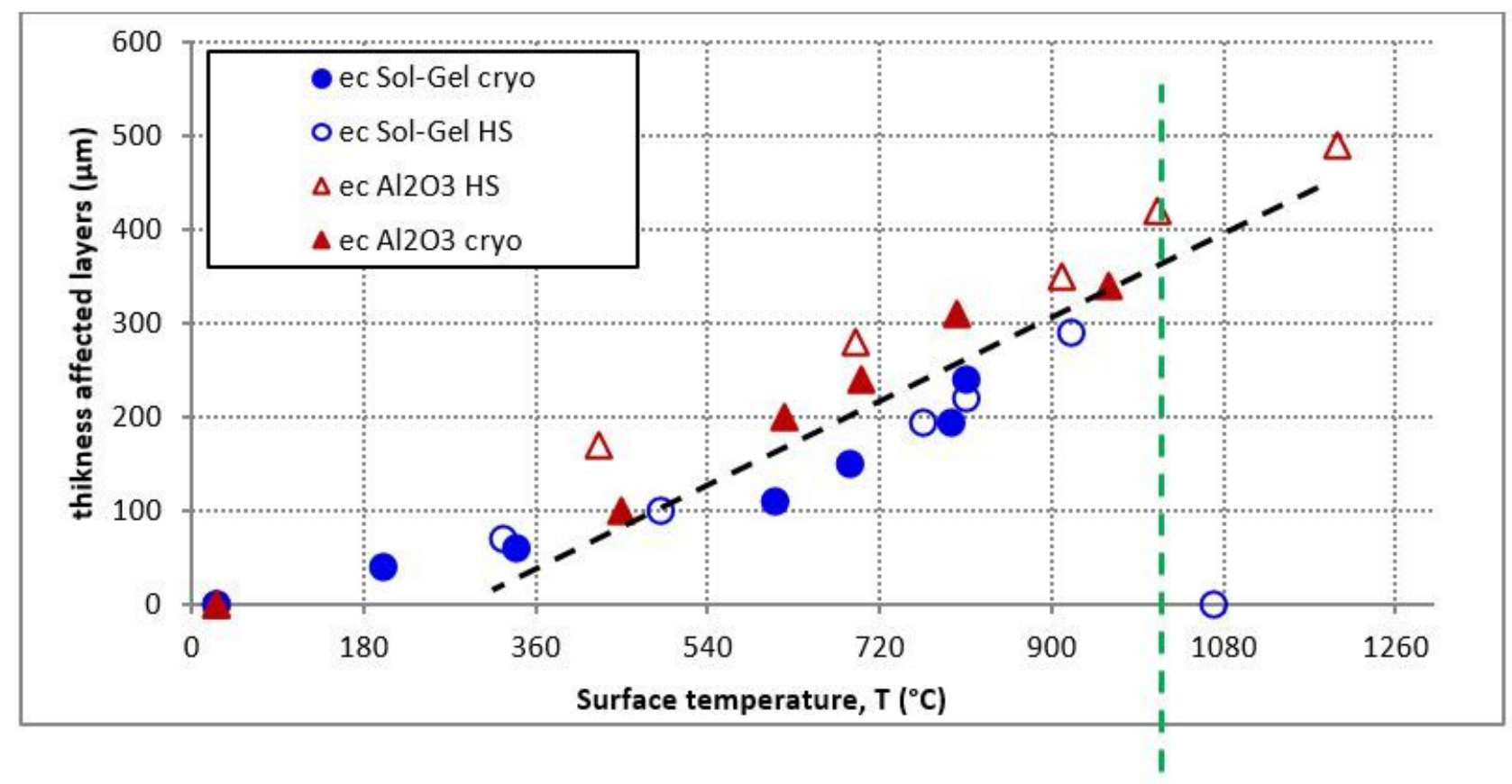

(b)

Figure 17

Effect of surface temperature on the depths of thermal affected layers and thicknesses layers to residual stresses of ground surface of AISI D2. (a) Depth of thermal affected layers and (b) thicknesses layers to residual stresses of ground surface 




(a)



(b)

\section{Figure 18}

Effect of temperature on surface integrity of AISI D2 tool steel. (a) Average length of thermal crack and (b) Thermal crack density 




Figure 19

Effect of temperature on surface productivity of AISI D2 tool 